\title{
Downstream Ecocide from Upstream Water Piracy
}

\author{
Miah Muhammad Adel \\ Department of Chemistry and Physics, University of Arkansas at Pine Bluff, \\ Interdisciplinary Sciences Research Center, 1200 North University Drive Pine Bluff, AR 71601, USA
}

Received 2012-05-20, Revised 2012-09-03; Accepted 2012-09-04

\begin{abstract}
Upstream India and downstream Bangladesh share more than 50 international rivers. India has set up water diversion constructions in more than $50 \%$ of these rivers, the largest one being on the Bangladesh's northwest upon the Ganges River, puts Bangladesh's Gangetic ecosystem at stake. In some border rivers, India has set up groins on her side of river banks. Also, Indian side pumps Bangladesh river water stealthily from border-rivers. Further, India is constructing another dam and reservoir upstream on the Barak River on the northeast of Bangladesh. Furthermore, India has chalked out a grand plan for river networking. Exploration has been made to assess the degree of the ecosystem degradation both inland and on the coast due to all water diversion constructions around the border, except for the Tipaimukh Dam in which case estimation of projected ecosystem degradation has been mentioned. Finally, Indian grand plan of river networking plan has been briefly touched upon. Site visitations, observations, surveys, measurements and interviews of professionals were made in the project country. Relevant literatures on this issue were reviewed in electronic and print databases. Related published articles in electronic and print media were systematically searched following the key words for the case. Finally, both electronic and print news media have been closely followed to know the latest developments on this issue. The reduced flow of the Ganges in Bangladesh has caused scarcity of fresh water, species endangerment and extinction, obstruction to livestock raising, loss of livelihoods, people's displacement, changes in crop production, reduction in navigable routes, extreme weather, increased flood occurrences, scarcity of potable water, groundwater contamination, reduction in coastal sediment deposition, deterioration of the Ganges water quality and inland intrusion of saline water front. Water diversion constructions in other rivers have caused similar type of ecological problems. The construction of groins on the Indian side of the border rivers has caused bank erosion on the Bangladesh side which changes her map. India benefits herself by occupying the resulting shoal formation within the Bangladesh side of the riverbeds. The Tipaimukh Dam on the Barak River will affect the virgin haor ecosystem the same way as the Ganges basin over a certain time scale. India's river networking plan is going to create a widespread ecocide in the Ganges-Brahmaputra basin. Water, if not the most, is one of the most important components in an ecosystem. Living being cannot survive without it. Ecocide occurs in its absence. Obstruction to the downstream natural flow of rivers by the upstream country unilateral actions is tantamount to violations of human rights which is a crime. With the dilapidated ecosystem, Bangladesh's national security is at stake. Bangladesh's internal immunity is not strong enough to face the threats of climate change events. Bangladesh government should take a tough stand for the country's interests. Since she has failed to save her interests on a bilateral basis with India, she should take immediate steps for fair share of the pirated river water under the UN supervision. Also, she should approach the UN for getting back the river shoals captured by India. Bangladesh should have a master plan of dredging rivers and canals for water storage and inland distribution to the depleted surface water bodies to reestablish the wetland ecosystem. This will help, to some extent, in the gradual mitigation of all the problems including groundwater arsenic contamination, fish scarcity, erratic climate. It is due for Bangladesh to charge the upstream country for the dredging cost of the rivers and canals since upstream country's water piracy has regionally silted her rivers and canals. Since the saving of the biodiversity is an international slogan of the time, Bangladesh should ask the UN to enforce strict international laws to stop any means of upstream water piracy including new constructions of dams, barrages, reservoirs, link canals upon international rivers to save the downstream biodiversity. Sanctions should be put in place for the violators of the law. Bangladesh's approach to international court may be an option, too.
\end{abstract}

Keywords: Animal Protein, Downstream Ecocide, Wetland Ecosystem, Erratic Climate 


\section{INTRODUCTION}

The South Asian country Bangladesh lies between $20^{\circ} 34^{\prime}$ and $26^{\circ} 38^{\prime}$ North latitude and $88^{\circ} 01^{\prime}$ and $92^{\circ} 41^{\prime}$ East longitude. An interconnected relationship binds her riverine wetland ecosystem elements-sunlight, water, air, soil, people, aquatics, amphibians, animals, birds, plants, trees and micro-organisms-to the extent that the loss of due proportionality of one can impact the rest. According to the Ramsar Convention more than two-thirds of Bangladesh are classified as wetland (http://www.environment.gov.au/water/topics/wetlands/ram sar-convention/index.html). Bangladesh's $6.7 \%$ remains year-round underwater, $21 \%$ accumulates more than $90 \mathrm{~cm}$ of floodwater and $35 \%$ accumulates shallow water. These water bodies include more than 1000 rivers 54 of which are international, natural lakes, reservoir, about 400 haors, 54,488 hectares oxbow lakes, 1,000 beels, 147,000 hectares of ponds and tanks, estuaries and seasonally water covered floodplains plains and 577,100 hectares of mangrove forests (FAO, 1988; Khan et al., 1994; Khan, 1993).

Bangladesh ecosystem survives on about 1200 billion cubic meters of river flows, 343 billion cubic meters of rainfall and 23 billion cubic meters of groundwater. The land drains the world's largest agricultural plain formed of (i) the Ganges, (ii) the Bhahmaputra and (iii) the Surma-Kushiyara-MeghnaBarak river basins (Fig. 1). In recent decades, it has been facing tremendous challenges to remain healthy, reproductive and sustained because of losing the due proportionality of its elixir element water. India deprived Bangladesh's inland and coastal ecosystems of about
$60 \%$ of Ganges water (Fig. 2) in the name of maintaining the navigability of Calcutta Port located about $370 \mathrm{~km}$ downstream of the Hooghly River, the south flowing canal-like off-shoot from the Ganges in India. It was the tributaries of the Hooghly-the Ajay, the Damodar, the Mundeshwari and the Rupnarayan-at its downstream that maintained Calcutta Port's navigability. Damming those tributaries reduced the Hooghly's flow and caused the siltation (Adel, 2012a). India availed the benefit of being an upstream riparian country to pirate Bangladesh's Ganges water. She pirates additional amounts of Ganges water by some 300 hundred large and small constructions located in Uttar Pradesh, Bihar and West Bengal on top of pirating water from $30+$ smaller size international rivers located around Indo-Bangladesh. Figure 3 below shows the rivers with water diversion constructions on them (Adel, 2001).

Major roles of wetlands are groundwater recharge, groundwater discharge, groundwater quality maintenance, floodwater storage, storm surge, irrigation, filtering system for polluted/stagnant water, shoreline stabilization and erosion reduction, obstruction to salinity intrusion, sediment trapping, soil fertilization, nutrient deposition, food chains maintenance, crop production, livestock grazing, fisheries production, essential minerals and other nutrients provision, wildlife habitat provision, sports and recreation facilitation, religious ritual observations, natural heritage values maintenance, aesthetic beautification, biomass production, wood/fuel provision, goods transportations, inland river port developments, bio-diversity presentation and micro-climate stabilization (Dugan, 1990; IWRB, 1992).

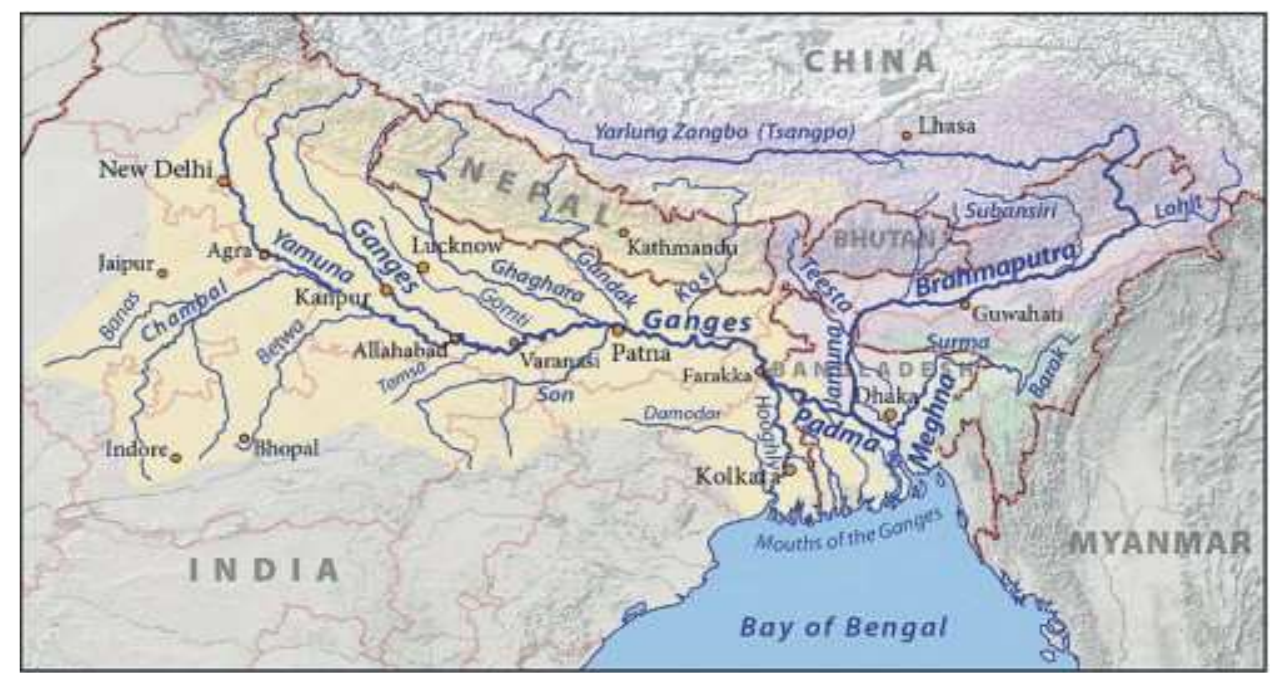

Fig. 1. The Ganga-Padma, the Brahmaputra-Jamuna and the Barak-Surma-Kushiyara-Meghna basin. (http://en.wikipedia.org/wiki/File:Ganges-Brahmaputra-Meghna_basins.jpg) 


\section{COMPARISON OF PRE- AND POST-FARAKKA ANNUAL AVERAGE} DISCHARGES THROUGH THE DELTA

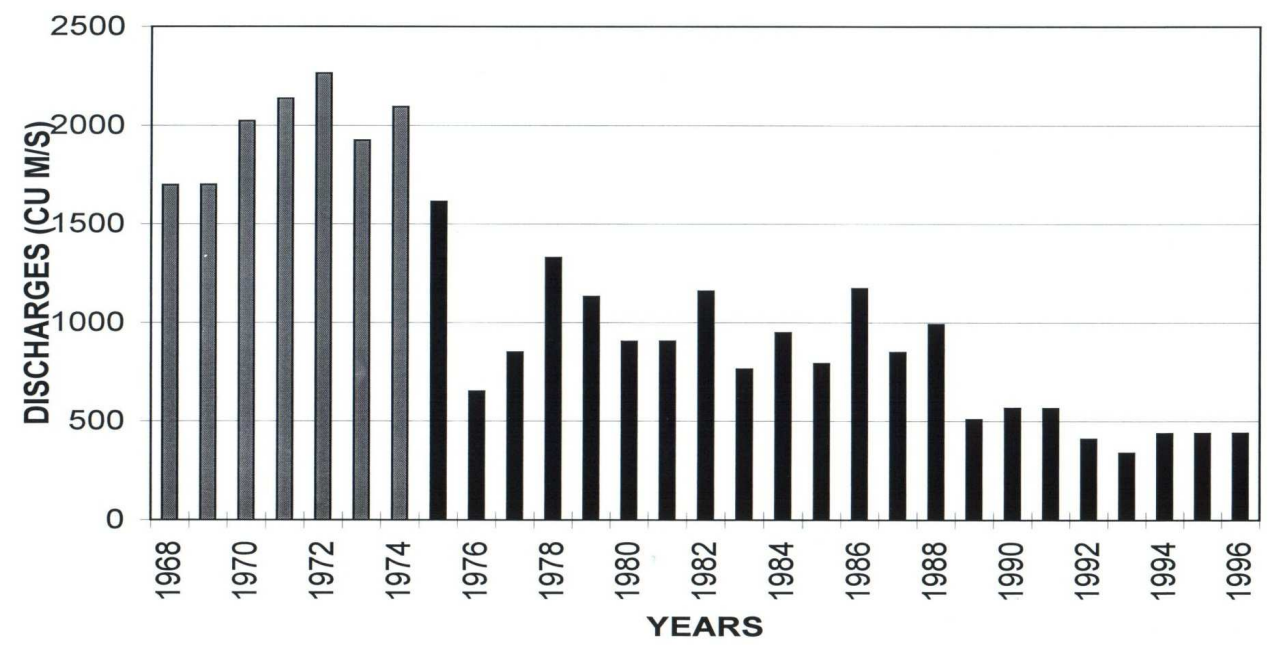

Fig. 2. Gangetic ecosystem in Bangladesh lost about $60 \%$ of its virgin water supply after 1975.
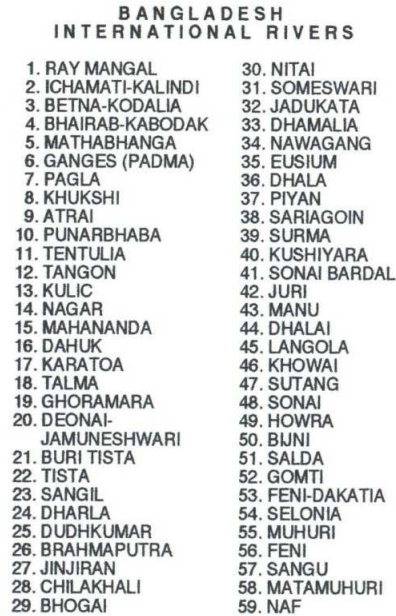
WEST BENGAL
RIVERS
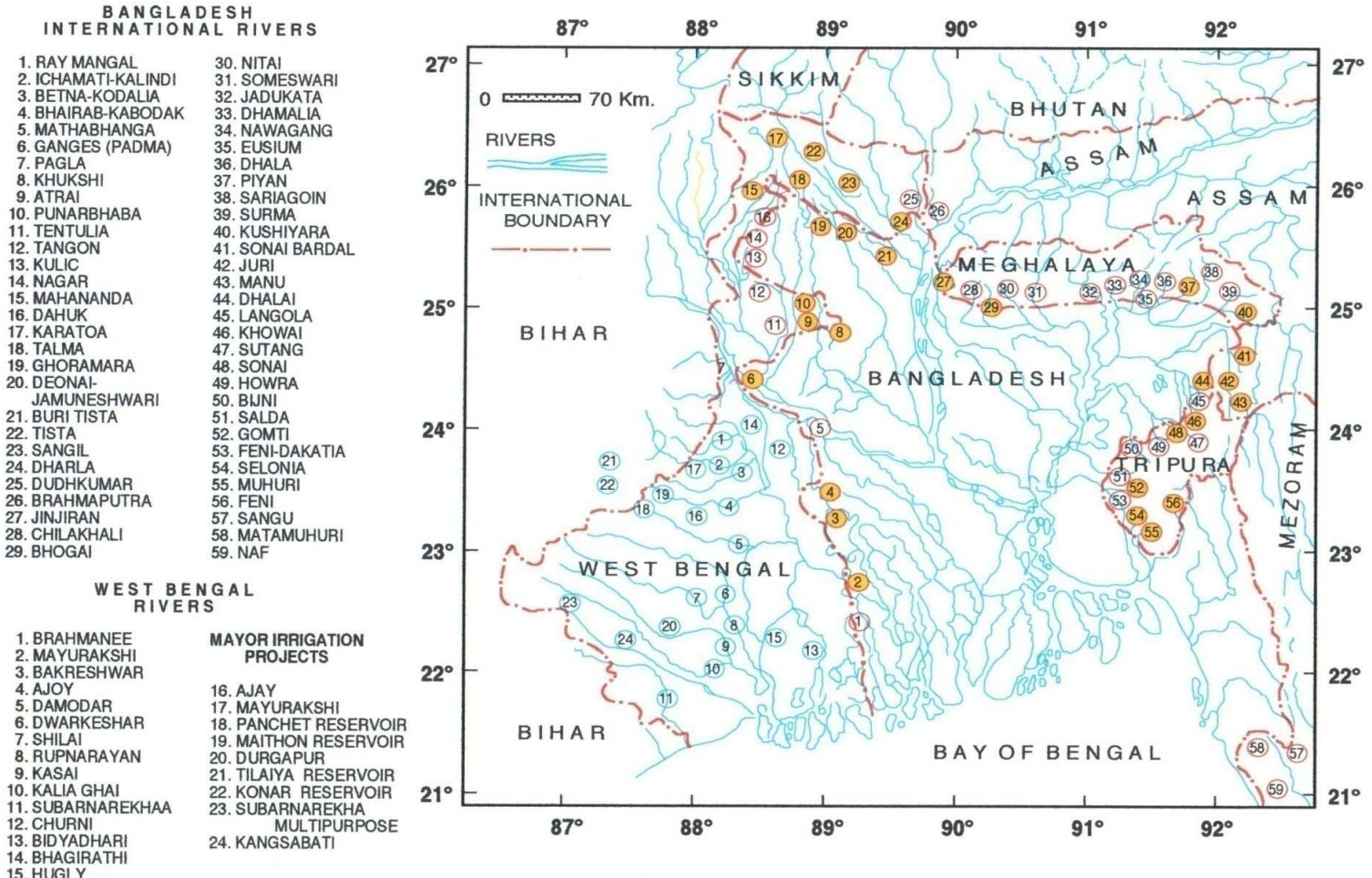

Fig. 3. Bangladesh, the dam-locked delta. Left side top shows the names of rivers. Water piracy goes upon, at least, the yellowspotted ones on the map. Left side bottom has the list of West Bengal rivers and the dams and reservoirs on the tributaries of the Hooghly River (Adel, 2001). 
This article focuses the condition of the Bangladesh ecosystem in the Ganges basin, other relatively small size river basins and the coastal areas and forecasts potential ecosystem damages on the Surma-KushiyaraMeghna basin and the Brahmaputra basin in the face of India's upstream water aggression.

\section{MATERIALS AND METHODS}

Affected area in the project country was visited, observations of the ecosystems changes were made, photographs were taken, surveys were made and measurements were taken. Relevant professionals involved in water-related projects were interviewed for important pieces of information. Systematic reviews were made of the relevant journal articles, reports, proceedings, books and websites. Finally, both electronic and print news media have been closely followed to know the latest developments on this issue. Every source of information that contributed to the preparation of the article has been properly referred in the Reference section.

\section{RESULTS}

\subsection{Musa Khan Basin}

The piracy of the Ganges water weakened its flow through Bangladesh silting the Ganges, its distributariesthe Baral, the Gorai, the Arial Khan, the Bhairab, the Mathabhanga, the Kumar and the Ichamati and the distributaries' distributaries-the Musa Khan, the Madhumati, the Pashur and the Kabodak. A huge shoal formed at the origin of the Baral and obliterated the origin of its distributary-the Musa Khan (Fig. 4).

All aquatics and amphibians that lived in a stretch of water of about $20,000 \times 12 \times 12 \mathrm{~m}$ during November through June and about $20,000 \times 100 \times 10 \mathrm{~m}$ during July through November in the Musa Khan were wiped out before making an inventory. It is a huge loss of biodiversity. Sportive Gangetic dolphins that would add a spectacular sight lost their habitat the river itself (Fig. 5).

More than 50 canals would carry the Ganges water to floodplains in its basin areas of more than $900 \mathrm{sq} \mathrm{km}$ during July through November. Those floodplains were the natural breeding and raising grounds for fishes and natural wells for recharging groundwater. The ecosystem can no longer render these services. Rice producing floodplains would turn into public fishing places. Fish was the cheapest source of calcium $(25 \%)$ and animal protein $(6.25 \%)$ for the basin people (Ahmed and Hassan, 1986). While population has been on the rise, these resources have been depleted. People naturally suffer from nutritional deficiencies.
At of the end of the last century, surface water bodies like floodplains and ponds lost $50 \%$ of their water budget. Years after years, the lack of timely available oxygen-rich adequate amount of water obstructed breeding and raising ground of fishes. Fish production dropped by, at least, $75 \%$. Several species have been marked extinct and endangered. Currently, fish is raised in few ponds with the help of groundwater (Adel, 2012b). An ecosystem that raised fish in natural water bodies for public consumption shrank down to a few private ownerships.

In the Musa Khan basin, fishermen, potter men, boat makers, fishing weapon makers, fishing experts and boatmen formed $6.0,4.0,0.4,5.4,4.3$ and $0.9 \%$ of the basin population, all of whom lost their livelihoods. Further, after the receding of flood water, river bank and its shoals would be raising grounds for livestock and canals and ditches for raising ducks. This opportunity, too, is lost. Fishermen would supply fish fry and fingerlings for the basin people who owned ponds. Fishermen would lease some of the ponds and other water bodies. They would make the fish available in the local market. In one location, about 150 families of fishermen that would make 350 fishing nets of 20 kinds for catching 15-20 varieties of fishes lost their livelihood. An ecosystem that had been supporting knowledge of knitting varieties of nets, manufacturing different kinds of fishing weapons with bamboo strips, boats and earthenware for generations is gone forever.

Whether in rural or urban areas, people are $100 \%$ dependent on groundwater for household needs-cooking, cleaning, bathing. In water-abundant days, almost $100 \%$ of the rural families were dependent on surface water for almost $100 \%$ of the time (except for potable water) and $30-50 \%$ of the urban families were dependent on surface water almost year-round. In the nineties, every year groundwater table was sinking by at least $0.5 \mathrm{~m}$ (Dept. of Public Health Engineering, Rajshahi, Bangladesh, personal communication, 1995). In water-abundant days, all tubewells were set at shallow levels. Now these are set at 7-10 times that depth. India's water aggression has gone to such an extent that the ecosystem's water bodies lost their seasonal regaining capacity.

The Hindu community would immerse statues of their gods and goddesses on the occasion of their religious festivals in the flooded Musa Khan River. A huge fair would take place by the Musa Khan bank. There used to be a Hindu funeral place by the side of the Musa Khan. Neither any immersion of the statues nor any funeral takes place in the Musa Khan. Water sports like swimming, boat race no longer take place in the basin. The pastime of angling is a forgotten recreation (Adel, 2002). The degraded ecosystem lost its capacity to provide these religious and cultural services. 
Miah Muhammad Adel / American Journal of Environmental Science 8 (5) (2012) 528-548

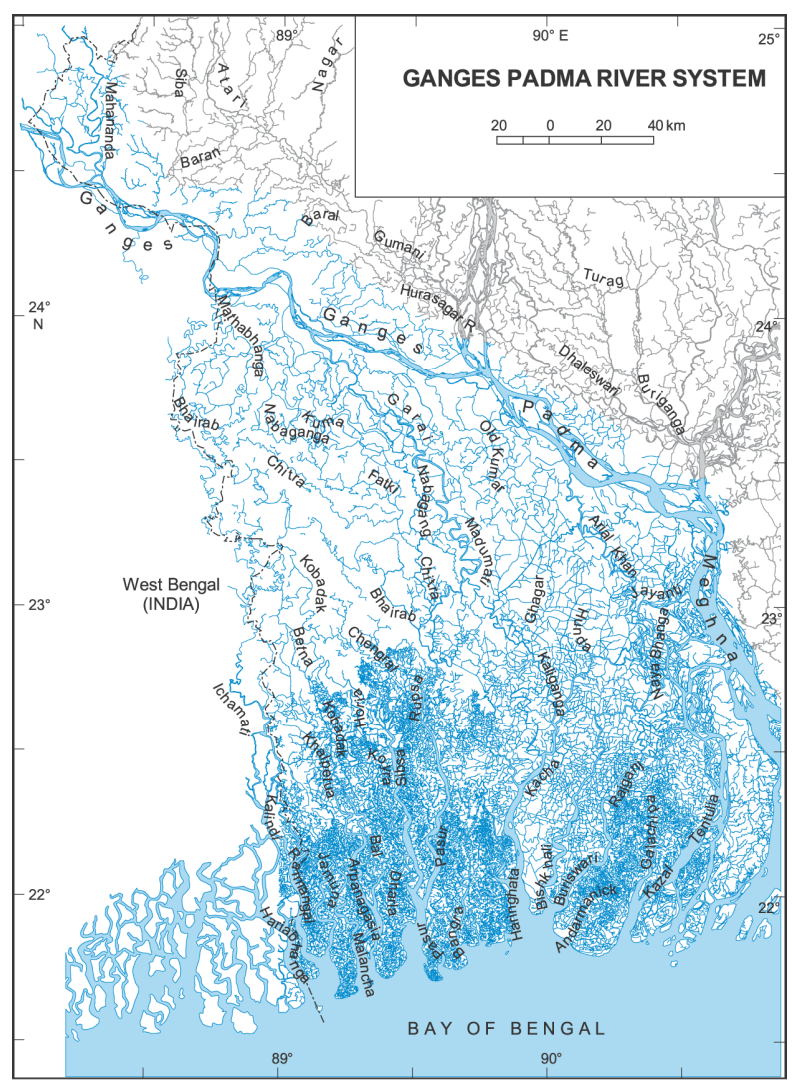

(a)

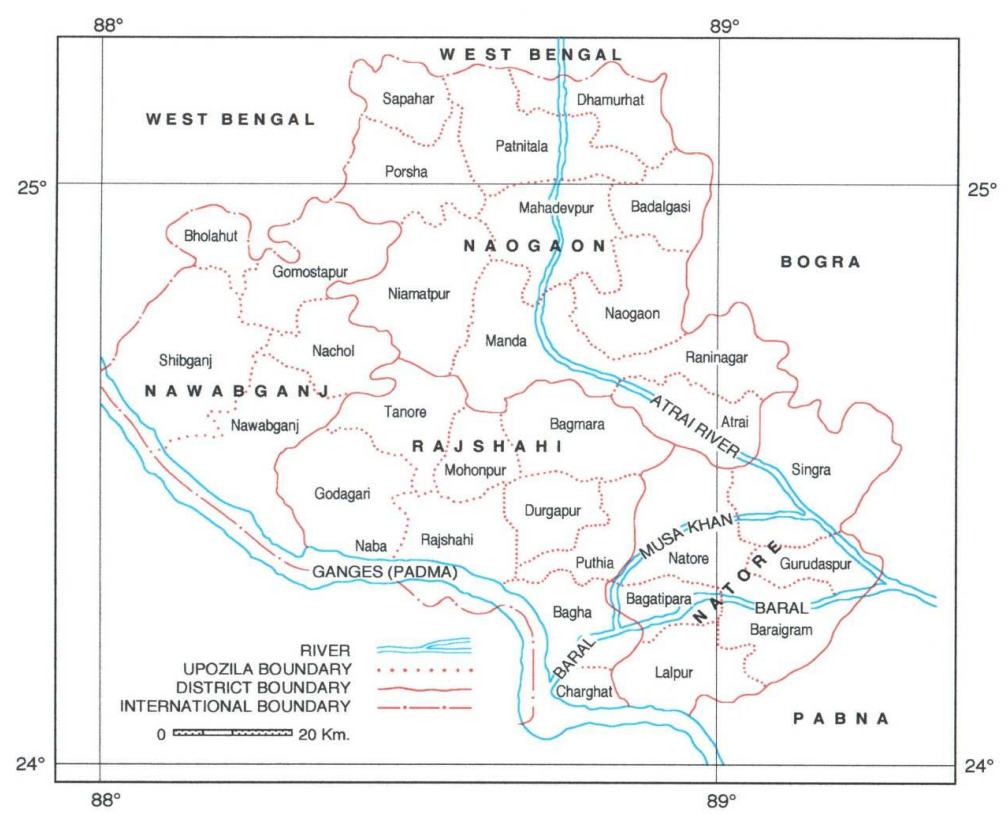

(b)

Fig. 4. (a) The Ganges-Padma basin (http://www.banglapedia.org/httpdocs/HT/G_0027.HTM) (b) Musa Khan basin (Adel, 2001) 

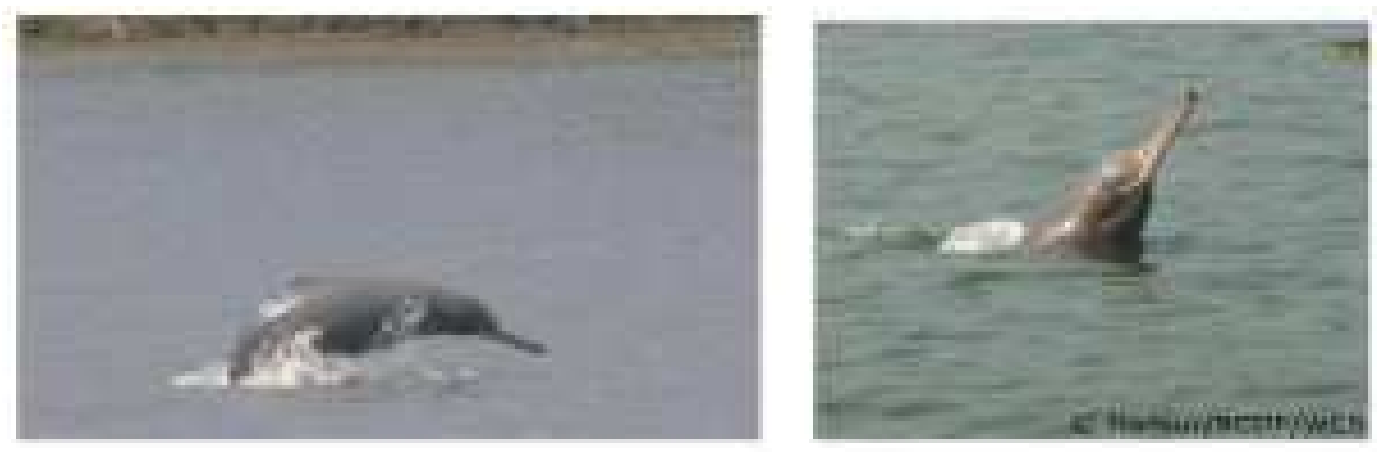

Fig. 5. At a time, dozens of Gangetic dolphins in the Musa Khan would arch their back above water and dive in (http://www.google.com/imgres? $\mathrm{q}=$ Ganges + Bangladesh\&hl=en\&sa=X\&rls=com.microsoft:en-us:IE-

Address\&rlz=1I7DKUS_en\&biw=1433\&bih=769\&tbm=isch\&prmd=imvns\&tbnid=1VfRE4KY60kslM:\&imgrefurl=http://th estickytongue.org/2012/02/17/bangladesh-dolphins-get-new-protected-

area/\&docid=3CFOm3bgD_zqpM\&imgurl=http://thestickytongue.org/wp-content/uploads/2012/02/Ganges-River-

Dolphin.jpg\&w=400\&h=280\&ei=sNC4T9vpI4bDgQfewbnQCg\&zoom=1)

With the dying of the Musa Khan, about $80 \%$ of the hand-tubewell by the riverside became contaminated with arsenic to varying degrees, some to the extent of $100 \%$. The arsenic contamination of groundwater has caused the world's largest man-made disaster. Married arsenocosis patients do not get the caring services by their husbands. It has created an additional social problem.

Ganges water would bring nutrients to rice fields. Rice land ecosystem would shelter frogs, snails, turtles, reptiles and disliked aquatics whose decomposed bodies would add about $1 \mathrm{~kg}$ of organic matter $100 \mathrm{sq} \mathrm{m}$ of inundated soil. For decades, the soil element of the ecosystem has not received the nutrients.

Evidences exist that people as far as from deep south Barisal used to come for trading purpose to the weekly market places by the Musa Khan. Distributaries provided cheap inland transportation routes, reducing costly and accident-prone land transportations.

Dammed rivers have been causing unprecedented floods. Floods cause irreparable damages to crops, livestock and above all, humans. The flood of 2000 inundated areas in Rajshahi, Nawabganj, Kustia, satkhira and

jessore

(http://www.google.com/search?q=Flood + pictures+of+B angladesh\&rls=com.microsoft:en-us:IE-

Address\&ie $=$ UTF-8\&oe $=$ UTF-

8\&sourceid=ie7\&rlz=1I7DKUS_en). In Rajshahi, dead bodies were seen floating in the Ganges. Many people from India took shelter in northwestern and southwestern parts of Bangladesh. It is reported that Bangladesh border forces had to guard against the upstream country's border forces' action of water release through Bangladesh (NFB, 2000).
Climate has become extreme to the extent that the maximum summertime temperature rose from 98.6 to $109.5^{\circ} \mathrm{F}$, often occurring temperature from 87.8 to $90^{\circ} \mathrm{F}$, average temperature from 85.6 to $87.4{ }^{\circ} \mathrm{F}$, HDD increased by 1.33 times and about 70,000 million billion calories of heat are produced in the environment in the absence of water bodies. The wintertime minimum temperature dropped from $46.6^{\circ} \mathrm{F}$ to less than $41^{\circ} \mathrm{F}$, often occurring temperature from 78.8 to $77^{\circ} \mathrm{F}$, average temperature from 68.5 to $67.6^{\circ} \mathrm{F}, \mathrm{CDD}$ increased by a factor of 1.44 and about 70,000 million billion calories are lost from the environment without the water bodies the ecosystem had before. The occurrences of the highest relative humidity rose from 1635 times to 2957 times, maximum relative humidity rose from 90.21 to $92.54 \%$, the minimum dropped from 55.2 to $52.9 \%$. Often occurring humidity rose from $65-70 \%$. Frequency of light rainfall increased, but the frequency of the heavy rainfall $(>100$ $\mathrm{mm}$ ) dropped by $50 \%$ (Adel, 2002). No rainfall occurred in 2009-2010. Heavy rainfall occurred in 2011. The entire riverine ecosystem has turned into a dead river dry land one. The 2012 summer has become unbearably hot. Rainfall occurred before the advent of the monsoon season. The sowing season of 2012 has not received any rainfall at all. These facts sound like a legend now.

\subsection{Other Regional Pictures}

In other distributaries, on December 15, 1995, the mouth of the Garai closed totally. The Kumar, the Kalindi and the Dakua rivers were in terrible shape. These distributaries of the Garai were about to be leveled off. The Kabodak River lost its flow. The Teka River and the Shree River are now forgotten by people. These rivers 
are the internal ones. The dam-locked international rivers are shown in Fig. 1 above.

More than 75,000,000 people are affected by arsenic poisoning in Bangladesh. Arsenocosis patients feel tired, fatigue, weak. Leprosy-type sores appear on toes and/or palms of hands. Burning sensation put the patients at unrest. Families are broken following wife's arsenocosis. 1 in 5 deaths in Bangladesh is linked to arsenic drinking water (Director of the Center for Cancer Epidemiology and Prevention, University of Chicago Medical Center).

As to the declining ground table, in 1995, 155,000 shallow tubewells in 192 upojillas in 36 districts failed to extract water. As a result 464,300 ha Boro and Irri fields could not be irrigated (Sattar, 1996). This shortage of groundwater is never replenished.

As to the loss of inland waterways, in 1970 inland navigable routes totaled about $4,000 \mathrm{~km}$. Around the mid-nineties, it reduced to $950 \mathrm{~km}$. In the dry season, $3,050 \mathrm{~km}$ inland waterways in the Ganges and its distributaries lost navigability. These are Godagari to Goalando in the Ganges, Rohonpur to Godagari in the Mahananda, Charghat to Bera in the Baral, Pabna to Bera in the Ichamati, Bardia to Khulna in the Bhairab and the entire Musa Khan. Additionally closed routes are, Benogati to Gajirhat in the Chitra, Magura to Bardia in the Nabaganga and Manikdah to Khulna in the Ankabanka (Fig. 4a above). It is about six times cheaper to travel in river routes than on highways.

National production of fish in pre-Farakka days was 277,000 metric tons. In 1991, it dropped to 185,000 metric tons. Livelihoods of about 200,000 people were directly or indirectly dependent on the fish resources. As of the mid-nineties, Bangladesh lost Tk. 63,000,000,000 in fish resources (Sattar, 1996). Hilsha fish spawn cannot tolerate salty water. Weakened flow in the Ganges caused problems in hilsha spawning.

Death of a river causes an irreparable and irreversible damage to wetland ecosystems.

\subsection{Water Piracy in Other River Basins}

India built theTeesta Barrage (Fig. 6) at Gazaldoba in the district of Jalpaiguri and diverts 54 cumic meters (1,900 cusecs) of water per second from the Teesta into the Mahananda in the dry season. It has created problems in agriculture and navigation. Bangladesh Teesta Barrage have the plan to irrigate, control flood and drain 35 upojilas in the districts of Rangpur, Dinajpur and Bogra. It has the capacity to irrigate 540,000 ha and benefit 750,000 ha land. However, Indian Teesta Barrage controls the flow making Bangladesh Barrage almost inoperative. Agriculture and navigation have been tremendously affected.
The Mahanda River is the only tributary of the Ganges in Bangladesh. India constructed two dams upon the Mahananda River-one at two miles and the other at 20 miles upstream (at Khodaimaree) of Tentulia. A $42 \mathrm{~km}$ long canal links the Teesta and the Mahananda rivers (Fig. 7). Water is diverted from the Mahananda during the dry season resulting weakened downstream flow. India controls water flows in the Mahananda, the Korotoa, the Teesta, the Bhaluka, the Ranchandi, the Talma, the Ghoramara, the Buriteesta, the Bhersa, the Chilok, the Balam, the Pisla, the Dahuk, the Chawai and the Kurum in the greater districts of Dinajpur and Rangpur. It has affected livelihoods, agriculture, industry and natural balance:

- The Bangu River has a regulator at Kashiabari, Mekliganj Subdivision of Jalpaiguri District

- The Khukshi River has a barrage at Jhenaipose in Balurghat

- The Soto Jamuna River in the Dhamoirhat Police Station in the Naogaon district suffers from water shortage

- The Talma River has a barrage at the spot opposite to the Bhitorgahr border post of Panchgahr Police Station in the district of Panchgahr

The Bhairab River once flowed from the Ganges across the current bed of the Jalangi River (Fig. 8). It is no longer an active river. It was the source of water for the rivers in the districts of Jhinaidah and Jessore. It has a cross dam near the origin at $8 \mathrm{~km}$ downstream from Gangarajpur at Karimpur Police Station of the Nadia district; also, one regulator has been set upon the Jalangi River upstream of the dam. Following India's unilateral withdrawal of the Jalangi River water, the Bhairab flow has been drastically reduced. Irrigation works in Meherpur and Chuadanga districts pass through a critical condition. The rivers in Jhenaidah and Jessore are dying. In the dry season, the Bhairab is a very dwindling river. Its salinity measures 10,000 ppm in March-April.

The Kodla River has one dam by the border post in the district of Twenty-four Parganas. Bangladesh part of the same river suffers from water shortage

The Madhumati River has one dam at Kakalmari.

The Korotoa River has one barrage built in the nineteen sixties at Ambari-Falakataya and currently brought under the Teesta Barrage (Fig. 7). Karatoa Barrage gets 425 cusecs water through a feeder canal from the Teesta-Mahananda Link Canal.

Indian built dam on the the Jinjiram River in Meghalya affects agriculture over a few hundred sq km of land by the river bank. Both irrigation and flood problems haunt this river basin. 
Miah Muhammad Adel / American Journal of Environmental Science 8 (5) (2012) 528-548

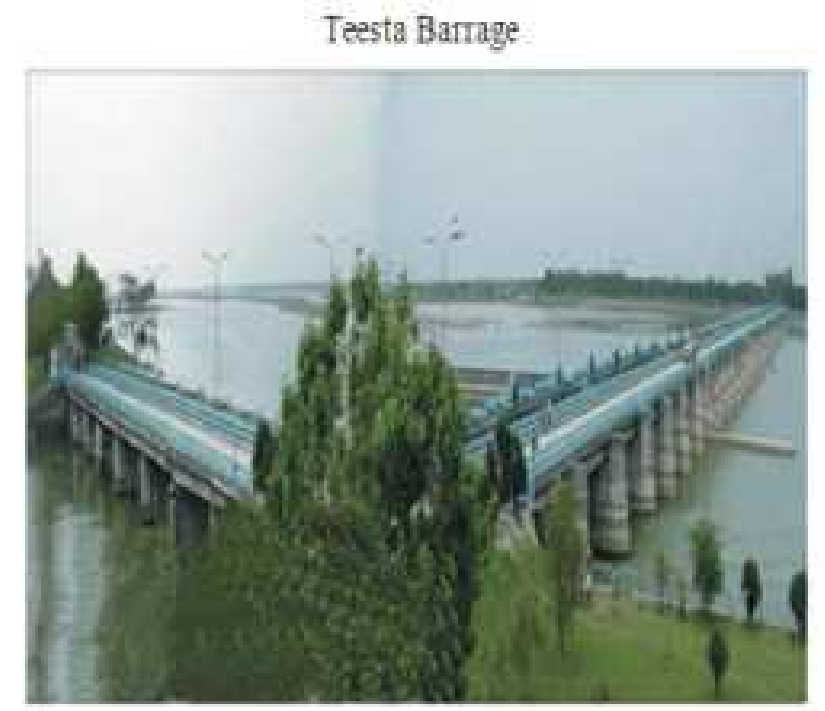

Fig. 6. Indian Teesta Barrage (Courtesy of Wikipedia)

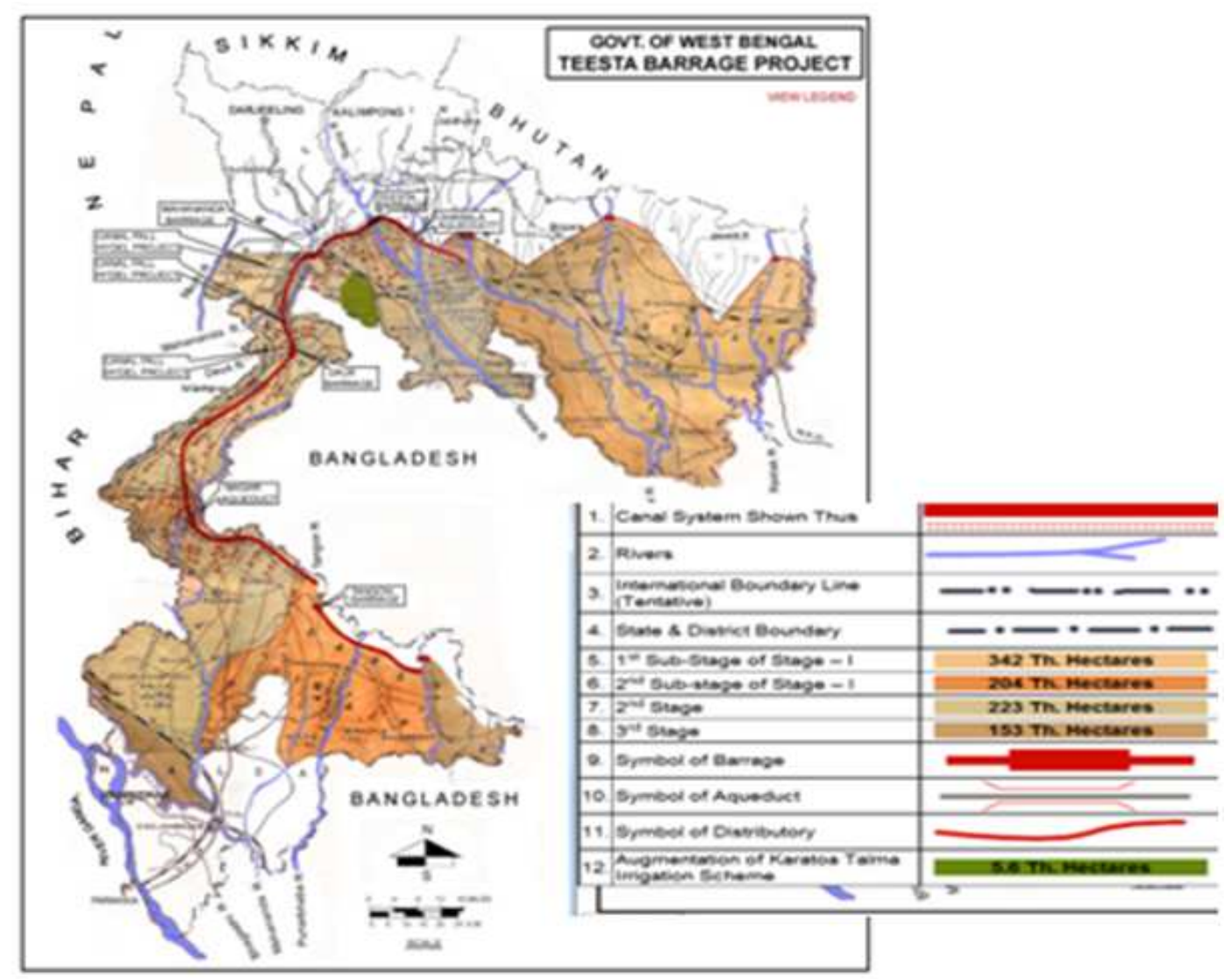

Fig. 7. Teesta-Mahananda Link Canal (Courtesy of Wikipedia) 


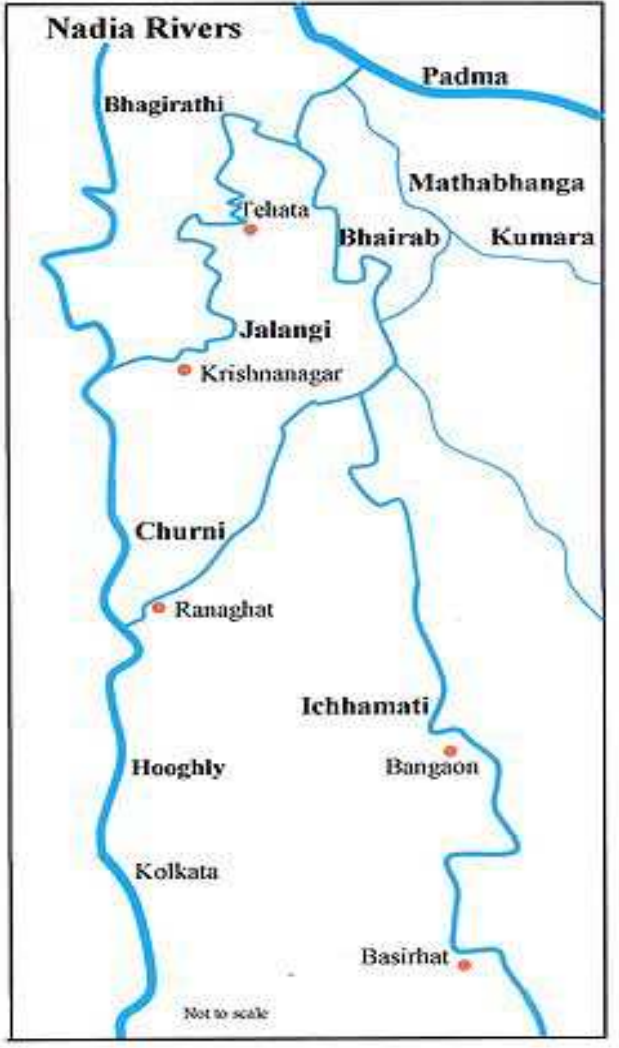

(a)

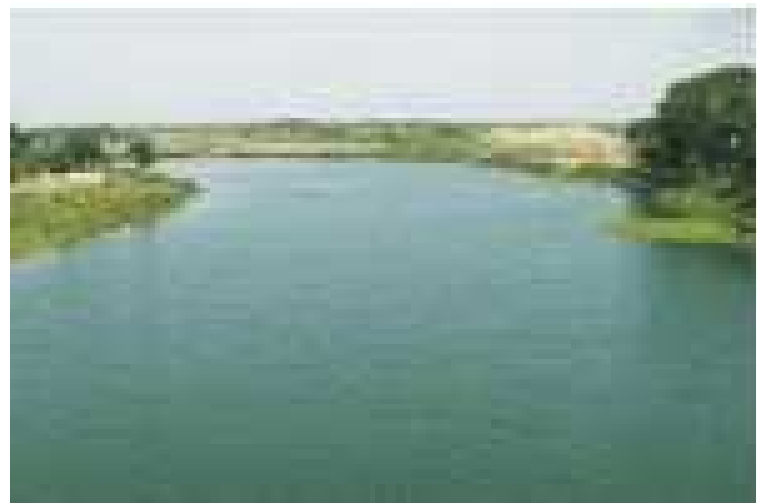

(b)

Fig. 8. (a) The courses of the Jalangi, the Mathabhanga, the Ichamati and the Bhairab Rivers (b) The Jalangi River in West Bengal, India (http://en.wikipedia.org/wiki/Jalangi_River)

India's construction of a dam at Mathrani upstream of the Gomti has affected the Sonai Sari Irrigation Project in Comilla that needs 150-200 cusec of water.

India built two dams over the Khoi River-one at Chakma Ghat and the other at Kalyanpur in Tripura. About 25,000 acres of land are irrigated for cultivation of Irri and Boro. In the dry season, its flow is 8.5 cumecs (cubic meters per second). The Manu River flow in the winter is 14-17 cumecs. Its flow increases five times during the flood season. Its upstream barrage at Kanchanbari near the Kela City in Tripura, India, controls the flow.

India has built a dam on the Dhali River in Tripura. This Moulvi Bazar river flow is controlled by that dam.

The Punarbhaba river faces a dam at Komordanga at the upstream over the Punarbhaba to use its water. It creates scarcity of water in the northern districts of Bangladesh.

The river Pyan/Doukee faces a 43-m long, 9-m wide and 9-m high groin over the Douke River in Assam that obstructs its original flow. India destroyed the Bangladesh boundary pillar when constructing the groin. India put concrete on the western side of the Ichamat-Kalindi River to stop erosion. As a result, erosion takes place on the Bangladesh side, shoals appear in the river, India captures them, plants trees and demands as their own. The map of Satkhira District has been changing. The river eroded 50 mowjas of Kaliganj, Shayamnagar, Kalaroa, Debhata and Satkhira upojilas. BGB's Shakra Border Post has been eroded. India built a groin on the Kushiyara River which has $33 \mathrm{~km}$ border with India. The river erodes Bangladesh side. A huge area of the Jakiganj Upojila is in the river. As shoals form, India captures them. The original place of the Jakiganj town is under Indian occupation. She named it Char Bajar. The areas of the Jakiganj Upojila that were eroded are Amalsid, Manikpur, Shahisbag, Pinnakandi, Amalnagar, Gangajal, Dubaria, Bhuiar Mura, Lakshi Bajar, Ujirpur, Barapather, Majheer Gram, Suprakandi, Pearpur, Gadadhar, Lohar Khal. 


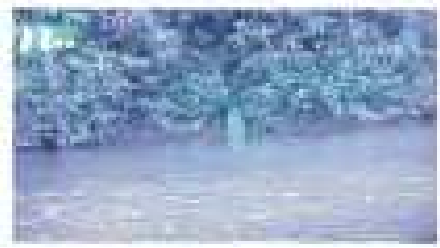

(a)

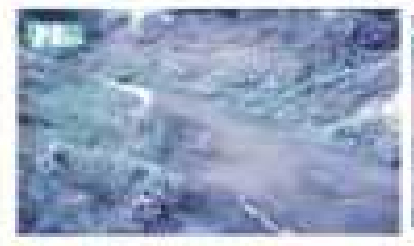

(b)

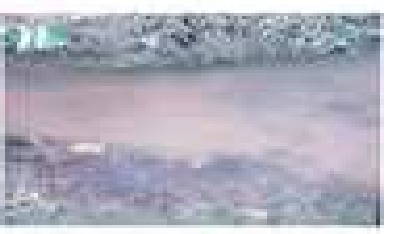

b)

Fig. 9. Once instance of India's water stealing from the Bangladesh's Feni River, (b) canals carrying water to distant farm lands lack adequate water for irrigation (Courtesy of ntv)

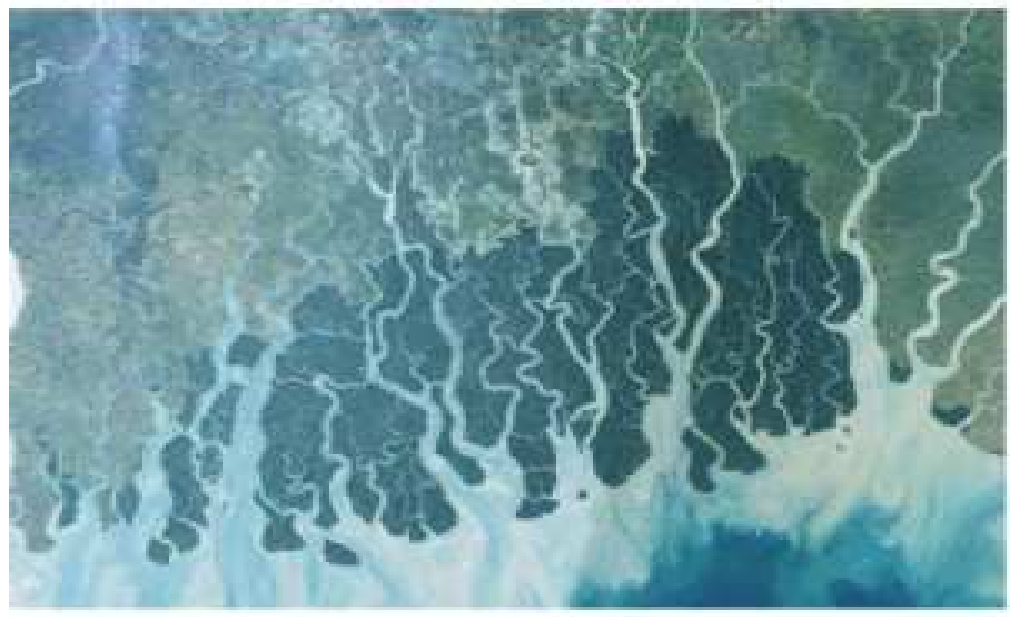

hitp:ipopsci typepad compopsci/200705 galleries of vi. leml

Fig. 10. The coastal Bangladesh

To save the town of Belunia on the bank of the Muhuri River India built nine spars and revetment. As a result, it erodes Bangladesh side and the resulting shoals are captured by India. Muhurir Char was originally within Bangladesh. It is near Parshram Upojila. This char is about 111 acres. In 1985, India occupied 53 acres of land from this char. Following Indian occupation, there was exchange of firings between the border forces of both sides on 26 June, 1993 (Sattar, 1996).

The construction of groins along with her follow-up activities proves a powerful neighbor's encroachment upon a weak nation. In all these water deprived river basins, scenarios like that of the dead river Musa Khan will be very common.

There have been instances of stealing water by India from Bangladeshi rivers Fig. 9. It reduces the water budget for the Bangladeshi farmers. Canal streams reduce and farmers have difficulty in irrigation. Also, canal water quality deteriorates increasing biological oxygen demand, Coliform bacteria and decreasing dissolved oxygen. Canal aquatics and amphibians fall at stake.

\subsection{Coastal Ecosystems}

Bangladesh coastal rivers total $24,000 \mathrm{~km}$ in length over an area of $9,380 \mathrm{~km}$ having many islands between channels Fig. 10. Krantz (1999) reports of an erosion of $68.4 \mathrm{~m} / \mathrm{yr}$ or $4.3 \mathrm{~km}^{2}$ over 5 years on the east side of the Island of Bhola and an accretion of $20.9 \mathrm{~km}^{2}$ during the same time on the west side and up in the north (http://www.gvc2.gu.se/BIBLIO/B-serien/B178.pdf).

SPARSO (1993) reports of $50 \mathrm{sq} \mathrm{km}$ loss due to erosion in the entire coast during 1976-1990. Their 1987 report shows net erosions of $280.70 \mathrm{sq} \mathrm{km}, 77.58 \mathrm{sq} \mathrm{km}$, $110.75 \mathrm{sq} \mathrm{km}, 78.45 \mathrm{sq} \mathrm{km}$ and $297.63 \mathrm{sq} \mathrm{km}$ in Bhola, Hatiya, Sandwip, Manpura and Sundarban area, respectively (http://saarcsdmc.nic.in/pdf/workshops/goa/bangladesh/Coastal $\% 20$ Erosion $\% 20$ Impact $\% 20 \& \% 20$ Adoption $\% 20$ aspect $\% 20$ fo r\%20Bangladesh.pdf).

Weakened flow in the Ganges progressively deteriorates Ganges water in the downstream-Dissolved Oxygen (DO) declines from 9.3-6.0 $\mathrm{mg} \mathrm{L}^{-1}$, biological oxygen demand increased from. 1.4-2.0 mg L $\mathrm{m}^{-1}$ and 
Coliforms (may indicate a presence of harmful, diseasecausing organisms called pathogens) increases from 20 to $15,500 \mathrm{MPN} / 100 \mathrm{~mL}$ (Jhunjhunwalla, 2009).

Bangladesh faces decreasing river water discharge due to upstream water piracy and sea level rise due to global warming (Aung et al., 2009). According to Agriculture Department 1,056,000 out of 1, 608,000 agricultural lands i. e., about $66 \%$ of the coastal land is saline. Salinity increases as time goes on. In 1973, 833000 ha land were saline (Weekly Thikana, 20 April, 2012). In 2009, the figure rose to $1,056,000$ ha. Dry season fluctuating river flows as stipulated in the 30 -year water sharing treaty aggravate the situation. The salinity front of 5,000 millimho intruded 90135 miles inland and spread from 7,000-12,000 sq miles. The salinity front of 20,000 millimho engulfed 5,000-8,000 sq miles. Coastal tubewells yield salty water. The salinity attacked 45 million trees and plants in 2,200-sq miles wide Sundarbans in the last century.
Freshwater Gangetic dolphins are threatened by human activity of damming rivers, inland salinity increase, industrial and agricultural pollutants and human sewage. Human activities have restricted their natural ranges and destroyed the spawning for the species of fish they prey on.

\subsection{HAOR Ecosystem}

Sylhet Division is about $8 \%$ of the total land area of Bangladesh. The core haor area is in the range of 4,45025,000 square kilometers. The haor basin consists of varying sizes of about 47 major haors and some 6,300 beels of which about 3,500 are permanent and 2,800 are seasonal. Haors of national and international importance are Tangua Haor, Pashua Beel, Gurmar Haor, Hakaluki Haor, Hail Haor, Kalaijuri Area, Companiganj Area, Companiganj Area Bara Haor, Kawadighi Haor and Balai Haor.
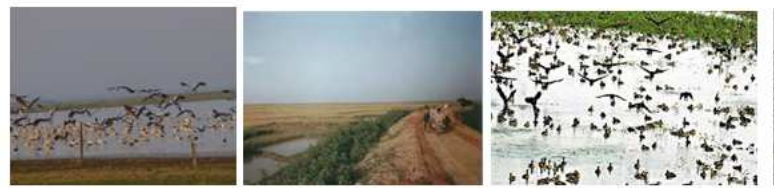

of

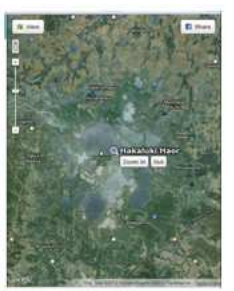

Hakakuli

Haor http://www.google.com/search?q=Hakaluki+Haor\&hl=en\&client=opera\&rls=en\&channel=suggest\&prmd=imvns\&tbm=isc $\mathrm{h} \&$ tbo $=\mathrm{u} \&$ source $=$ univ\&sa $=\mathrm{X} \& \mathrm{ei}=\mathrm{YGy} 4 \mathrm{~T} 8 \mathrm{iRH}$ smDsAKxm5GLDA\&ved=0CFoQsAQ\&biw=1096\&bih=656; http://you.travel/14749140

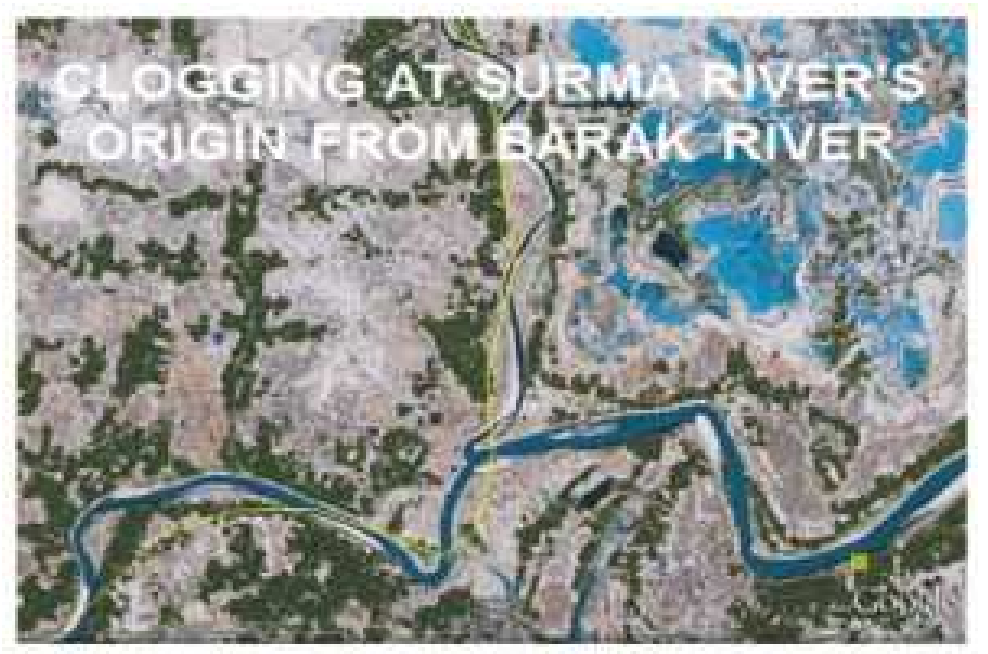

Fig. 12. The Barak-Surma-Kushiyara River basin The Surma goes upward and the Kushiyara downward. There is a huge shoal toward the end of the Barak as well as at the beginning of the Surma's course 
Haor basin is fed by the Surma and the Kushiyara. Their tributaries-the Manu, the Khowai, the Jadukhata, the Piyain, the Mogra, the Mahadao and the Kangsha form the drainage network of the haors. Out of these, Hakaluki Haor (Fig. 11) which covers an area of $181.15 \mathrm{sq} \mathrm{km}$, is one of the largest wetland water bodies in Bangladesh and also in Asia with more than 80 interconnected beels. The livelihoods of about 200,000 people living around the haor depend upon the haor $-32 \%$ lives on fishing, $29 \%$ duck rearing, $28 \%$ cattle raising, $6 \%$ fuel collecting, $3 \%$ sand extracting and $2 \%$ reed (marshy plant) collecting (Rana et al., 2010). The Juri, the Sonai Bardal and the Kushiyara feed this wetland. The Kushiyara river drains it out, too. Tens of thousands of migratory birds of about 150 species arrive here from the cold regions during the winter. At least 73 species of wetland vegetation are produced in the haor which is almost the half of the total of 158 . Haor raises more than 100 species of fish. It is one of the largest inland fisheries of Bangladesh. During the dry season, brood, young and juvenile fish take shelter in the haor.

The flood season (July-November) deposits rich alluvial soil in the haor, a boon for extensive rice cultivation.

India is building a $161 \mathrm{~m}$ high and $390 \mathrm{~m}$ long dam upon the Barak river (Fig. 12) in Assam, upstream of the Meghna to store $15.9 \times 10^{9}$ cubic meter of water (157 billion $\mathrm{N}=35$ billion $\mathrm{lb}$ ). The is the second main riverine ecosystem India is going to harm. The geological characteristics may not be able to withstand this additional stress under which it has never been. It may induce an earthquake drowning Bangladesh's one-third under 1 foot water. It may even be that an earthquake of certain strength can cause a resonance to destroy the structure. Tipaimukh dam is located $200 \mathrm{~km}$ upstream of Amalshit, the point where the Barak River splits into the Surma and the Kushiyara in the states of Manipur/Mizoram in India. The Surma-KushiyaraMeghna basin ecosystem is adjusted to the natural discharge of the Barak River. Human control of its flow will have grave consequences upon the ecosystem.

In the reservoir, Dissolved Oxygen (DO) will decline, Biological Oxygen Demand (BOD) will increase and Coliforms (may indicate a presence of harmful, disease-causing organisms called pathogens) will increases. Water released from the reservoir will erode the bed and the banks of the river. Riverbeds can be deepened by several meters within a decade. The erosion in the Kushiyara which carries $80 \%$ of the Barak flow will be aggravated changing the map of Bangladesh. The reduced flow will close the origin of the Surma River which has already got a huge shoal at this place. Closing of the Surma will have serious consequences upon the haor ecological system. Silted Surma will fail to receive water from its tributaries and to supply water to the network of shallow water routes leading to haors, beels. Timely unavailability of the adequate amount of water will affect breeding of different species of fishes. The fish resource will be depleted affecting people's livelihood, nutritional intakes. Navigable routes will be lost. Roads and highways will be under tremendous pressure creating fatal accidents. Also, the cyclical cultivation of crops will be impacted because of the unavailability of the haor land in the appropriate condition at the right time of the season. No more migratory birds will visit the area. Its aesthetic beauty will be gone (Fig. 13). Ecotourism will vanish.

With the irregular availability of the surface water resources, climate will behave erratically and temperature will turn extreme affecting production of tea and oranges. Rainfall will decrease. There will be continued shortages of recharging water. Groundwater table will decline. Subject to the availability of alluviumburied arsenic mineral and inflow of arsenic contaminated groundwater from elsewhere, groundwater will be contaminated. Basic social structure like marriages will be broken. Rehabilitation of arsenic patients will pose an additional social problem.

Further, the salinity front will advance further inland. Coastal erosion will supersede accretion. Haor ecosystem will face many risks of being unsustainable.

Mass agitations at different levels in Bangladesh and in the adjoining states of Assam have been continuing against this dam.

\subsection{River Networking}

India has announced a grand plan for river networking. Under this plan, she will divert 200 to 250 of BCM water from the Brahmaputra, the Teesta and the Meghna basins through link canals. This is the last and third main river basin ecosystem that India has planned to hit. There are fourteen links of the Himalayan components and another 14 links of the peninsular components. The Himalayan components are the Brahmaputra-Ganga (MSTG), Kosi-Ghagra, GandakGanga, Ghagra-Yamuna, Sarda-Yamuna, YamunaRajasthan, Rajasthan-Sabarmati, Chunar-Sone Barrage, Sone Dam-Southern Tributaries of the Ganges, GangaDamodar-Subarnarekha, Subarnarekha-Mahanadi, KosiMechi, Farakka-Sundarbans and Brahmaputra-Ganga (JTF)(ALT). The peninsular components are MahanadiGodavari, Godavari (Inchampali Low Dam)-Krishna (Nagarjunasagar Tail Pond), Godavari (Inchampali)Krishna (Nagarjunasagar), Godavari (Polavaram)Krishna (Vajayawada), Krishna (Almatti)-Pennar, Krishna (Srisailam)-Pennar, Krishna (Nagarjunasagar)- 
Pennar, Pennar-Chauvery, Chauvery-Vaigai-Gundar, Ken-Betwa, Prasbati-Kalisindh-Chambal, Par-TapiNarmada, Damanganga-Pinjal, Bedti-Varda, NetravatiHemavati and Pamba-Achankovil-Vaippar (Fig. 14).

In the second phase of the grand networking of rivers, a link canal will connect the Ganges with the Kaveri of south India. The canal will go from the Farakka point to Durgapur in the district of Bardhaman. From there it goes to the Darkeshwar river in the district of Bankura. From here the canal will be linked to many rivers of the province of Urissa. Then the canal links to the Krisna river through the Godavari river in the province Andhrya. Then the canal links to the Kaveri river in the Province of Tamil Nad. There will be many more small canals linked with the main canal. This artificial control of the river will make the Ganges dry. Also, the rivers-the Teesta, the Torsa, the Raydhak, the Jaldhala and the Mahananda that discharge water to the north-west Bangladesh will be controlled by India.

The environmental effect of the networking will be a wide-spread one. The flow in the Brahmaputra will be weakened. Its annual sediment is 527 million tons. Weak flow will favor quick sedimentation on the riverbed. Its distributaries are the old Brahmaputra and the Dhaleshwari. Its distributaries' distributaries are the Buriganga and the Shitolakhya. Quick sedimentation will occur at the origins of the distributaries and the distributaries' distributaries with the latter being affected first (Fig. 15). Soon their origins will be clogged. These rivers along with the floodplains they feed will be deprived of the water. Timely inadequate water is going to kill aquatic species in the Brahmaputra ecosystem.
This news of the river networking plan has created mass agitation worldwide. With the raised riverbed due to sedimentation, its tributaries-the Teesta, the Dharla, the Korotoa, the Atrai, the Subonsiri, the Hoorsagar will not be able to discharge their flow in the Brahmaputra. There will be shortage of surface water, recharging water, overdependence on the groundwater and water contamination. Climate will be erratic and turn extreme. Irregularity of rainfall will occur. People will lose their livelihoods. Biodiversity will be lost. There will be endangerment and extinction of species. Irrigation and agricultural and industrial production will be affected. There will be increased coastal erosion and wide spread inland advancement of the saline front. The scanty river water will suffer from biological oxygen demand and the presence of Coliform bacteria. Having lost the internal immunity, Bangladesh will be extremely vulnerable to global climate change effects.

\subsection{Signatory India's Disregard to the Ramsar Mission}

One of the oldest global environmental intergovernmental agreement is the Convention on Wetlands, also known as the Ramsar Convention established in 1971. The number of contracting parties is about 160 including Bangladesh's neighbor India. The mission of the convention is "the conservation and wise use of all wetlands through local, regional and national actions and international cooperation, as a contribution towards achieving sustainable developments throughout the world.

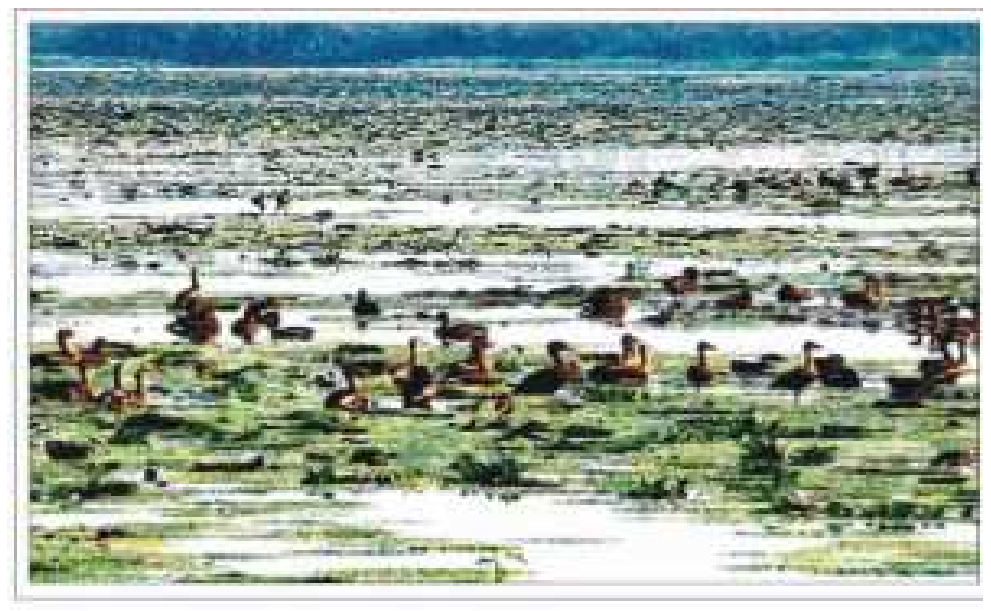

Fig 13. Guest birds in the Hakaluki Haor adds to its unparalleled aesthetic beauty. (http://www.google.com/search?q=Hakaluki+Haor\&hl=en\&client=opera\&rls=en\&channel=suggest\&prmd=imvns\&tbm=isc $\mathrm{h} \& \mathrm{tbo}=\mathrm{u} \&$ source $=$ univ\&sa $=$ X\&ei $=$ YGy4T8iRHsmDsAKxm5GLDA\&ved=0CFoQsAQ\&biw=1096\&bih=656) 
Miah Muhammad Adel / American Journal of Environmental Science 8 (5) (2012) 528-548
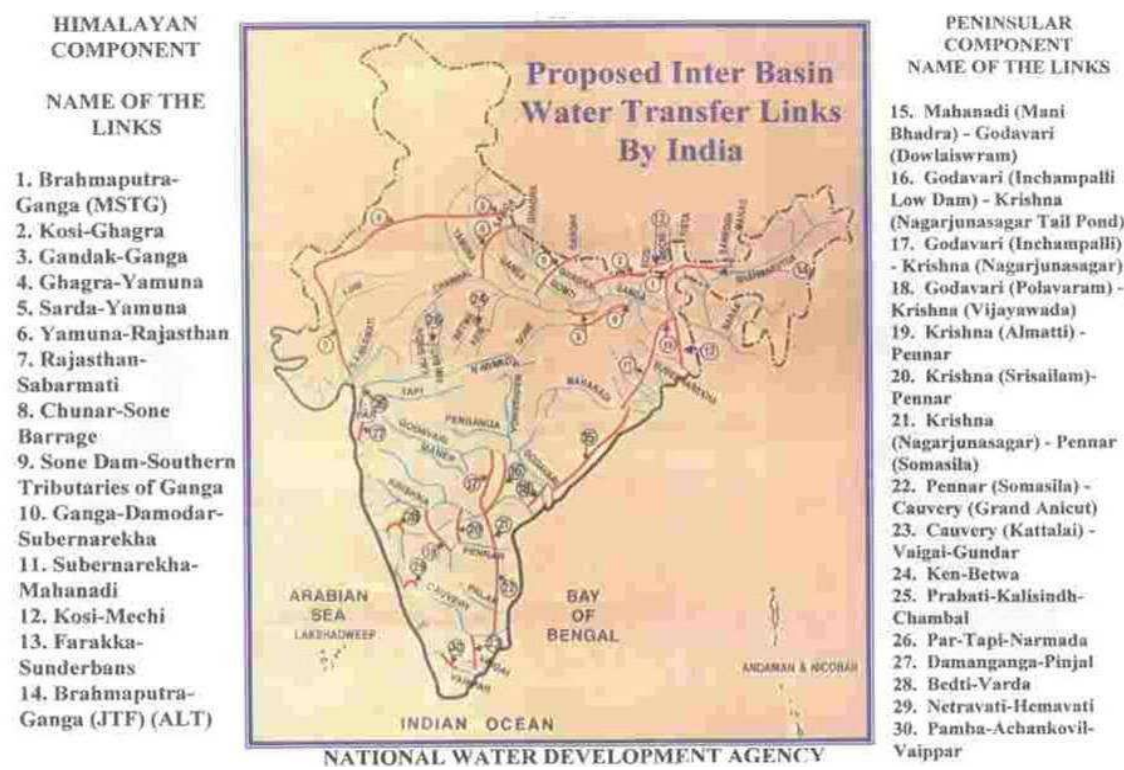

Fig. 14. India's grand plan of river linking

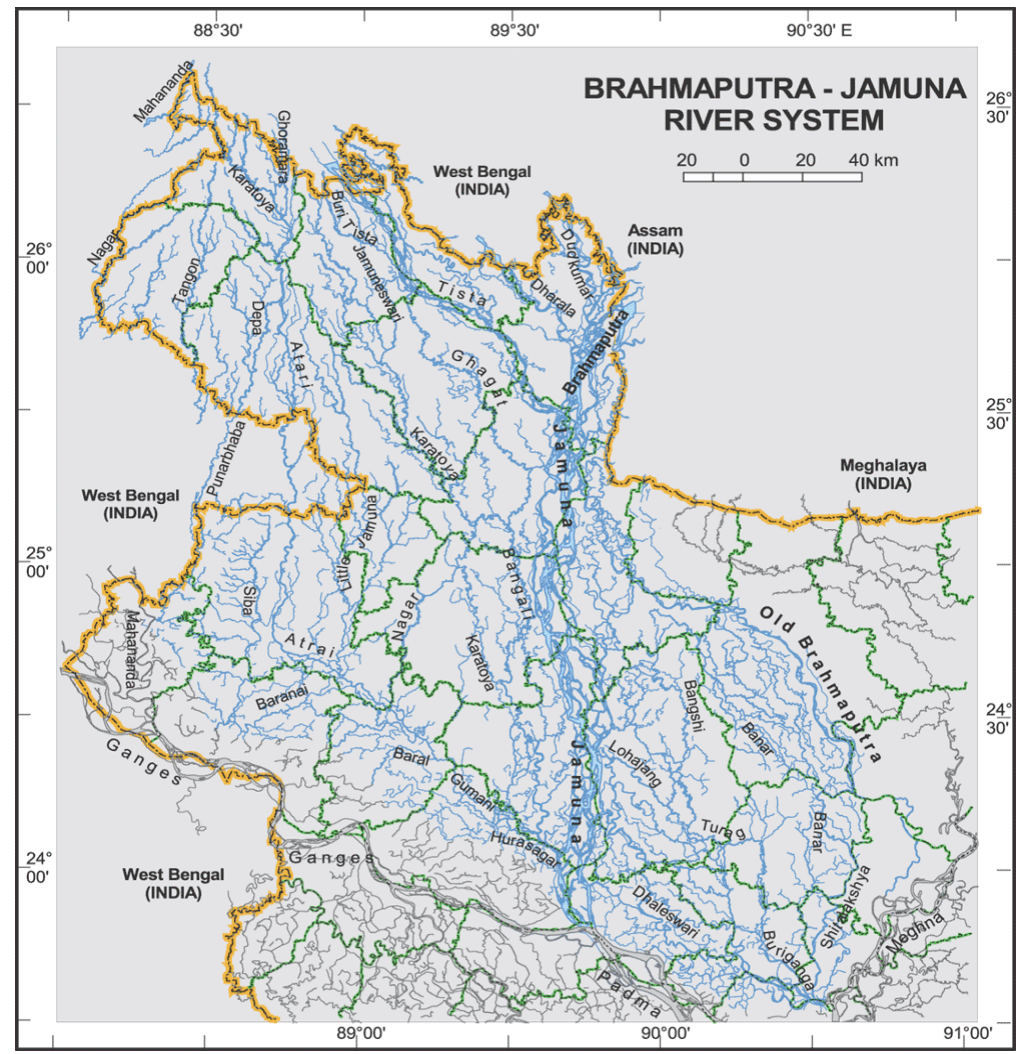

Fig. 15. The Brahmaputra-Jamuna basin. Many streams that off-shoot from the Brahmaputra's distributaries and the distributaries' distributaries and so on, will be affected in the reverse order because of the changes in direction and the weakness of flows (http://www.banglapedia.org/httpdocs/Maps/MB_0616.GIF) 
The three pillars of implementation of the contracting parties are:

- The "wise use" of all wetlands

- Special attention to internationally important wetlands and

- International cooperation

The convention's definition of wetland is "areas of marsh, fen, peatland of water, whether natural or artificial, marshes, lakes, rivers, peatlands, forests, karst and caves), coastal and near-shore marine wetlands (such as mangroves, estuaries and coral reefs) and humanmade wetlands (such as rice fields (paddies), reservoirs and fish ponds).

It is very difficult to deal with the mentality that does the things opposite to what is agreed upon by signing. If India honors the Convention, she should immediately stop pirating river water, decommissioning the dams and barrages and stop proceeding with new constructions.

\section{DISCUSSION}

\subsection{Musa Khan Basin}

The reason of the siltation is the slow moving current in the distributaries. The current at the downstream of a river is slowed down as it suplies water to its distributaries according to the equation of continuity:

$\mathrm{v}_{\mathrm{dn}}=\left(\mathrm{A}_{\mathrm{up}} / \mathrm{A}_{\mathrm{dn}}\right) \mathrm{v}_{\mathrm{up}}$

Where:

$\mathrm{v}_{\mathrm{dn}}=$ Velocity at the downstream

$\mathrm{v}_{\mathrm{up}}=$ Velocity at the upstream

$\mathrm{A}_{\text {up }}=$ River area of cross section at the upstream

$\mathrm{A}_{\mathrm{dn}}=$ River area of cross section at the downstream

The downstream river area of cross section becomes a few times larger than the upstream area due to the current split into the distributaries and subdistributaries.

A further reduction in speed results at the origins of the distributaries where the flow direction changes. If the distributary branches off at an angle $\theta$ with the river's downstream direction, ideally the current speed at the distributary's origin becomes $\mathrm{v}_{\mathrm{dn}} \cos \theta$. The slower the speed becomes, the shorter distance the suspended load travel before it falls through the water column. This sedimention at the origins of the distributaries and subdistributaries quickly clog their mouths. River bank erosion and anthropogenic activities raise the river beds and shrink the river width turing them to floodplains.
The Musa Khan River is about $20 \mathrm{~km}$ long. During the dry season, its average width would be about $12 \mathrm{~m}$ having an average water depth of about $2 \mathrm{~m}$. During the flood season, its average width would be about $100 \mathrm{~m}$ with an average depth of $10 \mathrm{~m}$. The river bed has stagnant water at scattered places that have increased biological oxygen demand and decreased dissolved oxygen and increased coliform bacteria which cannot be an abode for aquatics and amphibians. The river ecological system is dead now. Dozens of sportive Gangetic dolphins $1.5-2.5 \mathrm{~m}$ in length and up to $90 \mathrm{~kg}$ found in fresh water between 46 and $91^{\circ} \mathrm{F}$, would rise arc-like and majestic out of the water just about a meter or two away from boats that would ply the Musa Khan River. It would add a spectacular aesthetic beauty in the flooded Musa Khan. These fresh water dolphins have been threatened by human activity of damming rivers, inland salinity increase, overfishing, industrial and agricultural pollutants and human sewage. Anthropogenic activities have restricted their natural ranges by destroying the spawning grounds for the species of fish they prey on. Low Ganges River discharges increase the pollutant density.

The 20-km long Musa Khan River was the main source of water budget for the hundreds of floodplains that would raise many species of fishes along with production of rice. Flooded lands would lose their demarkation and would turn into public fishing places for about six months of the year. Timely unavailability of adequate water for the breeding and raising of fishes has depleted these aquatics. Poor people would have their calcium and animal protein needs fulfilled from catching fish in floodplains. Floodplain water would recharge the groundwater. The floodplain ecological system in the Musa Khan basin has disappeared.

Many people's livelihoods were tied to the live Musa Khan River. Fishermen living for generations on the Musa Khan River bank would live nine months of the year in boats. Their cottage industries of knitting nets for themselves and for selling to local people have been totally damaged. Fishermen would give service to local pond-owners in raising fishes in their ponds. There had been people-potter men, boat makers, boatmen, fishing weapon makers, fishing experts-who were serving the basin people seasonally and year-round have lost their generations-old professions. They would learn these skills at home and not in any institutions. These homegrown technological skills are no longer available.

With the loss of the surface water resources, people both in urban and rural areas heve become dependent of groundwater which is on the verge of depletion for extraction has been superceding recharging annually.

The Musa Khan's water was the source for observing the religious festivals and rituals of the main 
minority community the Hindus living in the Musa Khan basin. Its water was the source of leisure, recreation, sports activities. The Musa Khan can no longer serve these aspects of the local culture.

With the depletion of the the source of the recharging water and overdependence on groundwater, the generations-long used shallow groundwater table has been depleted. The deeper groundwater table has been sinking at an alarming rate. Groundwater table is found to be contaminated with arsenic. While the river sediment carried arsenic minerals and deposited in the alluvium, the natural deposition cannot be expected to be uniform. This makes arsenic contamination of groundwater not the same throughout the river basin. Arsenic minerals are inactive under water. As the groundwater table sank, the alluvium-burried arsenic minerals became exposed to atmospheric oxygen and formed water soluble compounds of arsenic that infiltrated to ground water. Oxygen dissolved in recharging groundwater can cleanse water of arsenic through precipitation. The ecosystem lacks recharging water to do that cleansing. As groundwater moves on different time scales from one point to another, contaminant is also transported the same way. These scenarios suggest that water scarcity is at the root of the arsenic crisis and it is said to be the world's largest manmade disaster that surfaced due to India's water piracy at the upstream (Adel, 2005) http://www.groundwater.conference.uci.edu/files/chapter

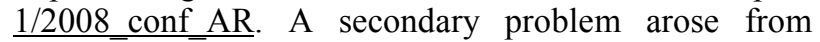
using filters to cleanse water of arsenic and dumping the arsenic sludge randomly in the environment - in water bodies and in open air. The result of this dumping is going to be very dangerous for the entire country. Evidence is surfacing that arsenic has entered into the food chain. The water that was available pure naturally needs quality assessment before using it (Durmishi et al., 2012). There is no end of the troubles arising out of the upstream water piracy.

The wetland ecology was the habitat for different kinds of amphibians and aquatics. At the end of the wet season, their decomposed bodies would add organic material to the soil. It may be mentioned that carbon in soil helps to retain water. For decades, the soil element of the ecosystem has not received the nutrients in the natural way.

Live rivers would provide cheap inland transportations. It would connect the deep south with the deep north. Now both the inland waterways and land transportations are huddled on the land causing transportation costly and causing many fatalities.

Upstream river dams and barrages are used as flood outlets during the flood season when the upstream country cannot withhold the rising floodwater. These outlets are opened without any warning to Bangladesh which is forced to face without preparation In the northwestern city Rajshahi that stands by the Ganges, dead bodies were seen floating in the Ganges. Many people from India took shelter in northwestern and southwestern parts of Bangladesh. Devastating floods occur due to the shrinking of the river and rise of riverbeds due to sediment deposition. Sediment deposition has already been discussed at the beginning of this section. Silted riverbeds fail to accommodate flood water. Prakash (1998) reported of about a meter silt deposition per year at Farakka.

The depletion of the surface water resources has made the climate extreme-desertlike climate. Water has the highest heat retention power. It can absorb heat during the summer and release during the winter to stop the fall of wintertime temperature. In the absence of surface water bodies, heat absorption and retention in the environment do not occur during the summer time. Heat reflection by the dry ground increases the summer time temperature. Winter time temperature drop is explained by the lack of heat reserve in the water medium during the winter. The rise of the occurrences of the highest relative humidity in summer time may be related to the evaporation of the groundwater extracted for irrigation. The occurrences of the minimum relative humidity may be related to the fact that it is observed in the morning hours when the air temperature is rising due to its low specific heat and water temperature is not rising because of its high specific heat and consequently low evaporation. The reduced occurrences of heavy rainfall in water-pirated days cause scanty recharge of groundwater because likely recharge occurs when (i) the soil has a high conductivity, (ii) the water table lies at shallow depth, (iii) the soil is relatively wet and (iv) the water input rate is low and lasts for a relatively long time interval (Freeze, 1969).

In view of the micro-level climate change and the over-extraction of groundwater, it has been imperative to study the groundwater flow systems and their response to this climate change.

\subsection{Other Regional Pictures}

Regional picture shows some aggregate effects upon the riverine ecosystem. The weight of this aggregate effects is much heavier than what happened in the Musa Khan basin. However, the same explanation of the effects hold true in the regional scennario as it holds true for the Musa Khan basin.

\subsection{Water Piracy in Other River Basins}

India pirates water not only from multi-national rivers like the Ganges and the Brahmaputra, she pirates 
water from bi-national rivers, too. About the sharing of the Teesta River water, in 1983 there was a memorandum of understanding between the two countries for releasing $36 \%$ water for Bangladesh, keeping $39 \%$ for India and the remaining $25 \%$ for the river itself. It has not yet been settled. In 1982, Indian Irrigation Minister Kedar Pande said of nearing the settlement of the Teesta water sharing. 30 years have passed without anything. A few months ago, Dipumoni, Bangladesh's Foreign Minister, said of signing the Teesta water sharing treaty on the occasion of Indian Premier Monmohan's visit to Bangladesh. According to Indian Foreign Foreign Minister, India needs a national consensus to come to the Teesta water sharing treaty with Bangladesh. Procrastination is an integral part of Indian politics. It may be mentioned that to get the minimum amount of water for the Bangladesh Gangetic ecosystem out of the unilaterally pirated Ganges water by India cost a marathon number of futile meetings between the two nations (Adel, 2005, http://www.groundwater.conference.uci.edu/files/chapter 2/2008_conf_AR.

The control of water discharge in the Mahananda River has affected livelihoods, agriculture, industry and natural balance. It has caused problems of water shortage, recharging water, water contamination and water-borne and water-carried diseases. It has destroyed biodiversity, natural breeding and raising grounds for fishes, inland navigable routes. It has generated extreme climate. The gross effect will sound astronomical had it been actually enumerated.

Rivers in Bangladesh are like arteries and veins in human body. With her river arteries and veins blocked, Bangladesh ecosystem has been paralyzed. Each river of Bangladesh-large multinational or small binational- had its own ecosystem. Indian desire to grow more and more food has caused ecocide in these river basins.

Other than building dams and barrages, building of groins is another Indian trick of changing Bangladesh ecosystems. When groins are built on the Indian side of bordering rivers, no bank erosion takes place on her side. All erosion takes place on the Bangladeshi side. Eroded land mass appears in the form of shoals in river beds which India captures. Even a battle was faught on June 26, 1995, between the border forces of these two countries because of encroached Indian occupation of Bangladesh land masses. India forgot the loss of lives in the battle and continue for easy capture of Bangladesh areas. India steals water from Bangladeshi, too, to irrigate land on her side. India has started an all out water agression upon Bangladesh.

\subsection{Coastal Ecosystems}

River sediment protect the country's shoreline against the sea's natural tendency to erosion. Rivers deposit the silt they carry at their mouths. Coastal erosion in Bangladesh is due to the upstream water piracy by India. The Ganges carries 794 million tons of silt annually. Out of this amount of silt, as inland deposition Ganges flood plains receive 65 million tons and Bangladesh flood plains receive 361 million tons. As coastal deposition, the Indian coast Bay of Bengal receive 361 million tons via the Hooghly River and the Bangladesh coast receives only 40 million tons via Bangladesh (Wasson, 2003).

A river's healthy indicator is the dissolved oxygen in the water. If it falls below 4 or $5 \mathrm{mg} \mathrm{L}^{-1}$, aquatic living beings begin to decline. The declination of dissolved oxygen is due to the reduced discharge rate and decomposition of organic matter. The Ganges get a lot of waste including dead bodies. After the winter, as the temperature rises, solubility of oxygen decreases on top of the weak discharge reducing the rate of atmospheric oxygen entrance to water. A fast moving Ganges stream used to have much higher rate of reaeration than a sluggishly moving Ganges water in the era of dams and barrages. The reaeration rate is given by (O'Connor and Dobbins, 1958):

\section{$\mathrm{k}_{\mathrm{r}}\left(\mathrm{DO}_{\mathrm{s}}-\mathrm{DO}\right)$}

where the reaeration constant $\mathrm{k}_{\mathrm{r}}=\left(3.9 \sqrt{ } \mathrm{u} / \mathrm{H}^{3 / 2}\right)$

$\mathrm{u}=$ Average stream velocity $(\mathrm{m} / \mathrm{s})$

$\mathrm{H}=$ Average stream depth $(\mathrm{m})$

$\mathrm{DO}_{\mathrm{s}}=$ Saturated value of dissoled oxygen

DO = Actual dissolved oxygen at a given location downstream.

A fast moving stream will have almost three times as large reaeration constant than sluggish streams and lakes and reservoirs and two times as large reaerations constant than a large stream of low velocity (Tchobanoglous and Schroeder, 1985). In the absence of chloride concentration in water, the solubility $(\mathrm{mg} / \mathrm{l})$ of oxygen in water at 1 atmosphere pressure is $11.29,10.08,9.09,8.26$ and 7.56 at $10,15,20,25$ and $30^{\circ} \mathrm{C}$, respectively (Thomann and Mueller, 1987). At 5,000 mg/L chloride concentration, these values drop by about 0.5 . According to treatment above, an increase of DO in thje Ganges water by a factor of about 1.5 is quite reasonable.

Salinity front makes its way inland following low river discharges. It is an unsurmountable problem for Bangladesh to stop advancement of the salinity front when upstream river discharges are pirated. The gross 
and net cropped areas in the coastal Bangladesh are 144,085 ha and 83,416 respectively (Islam, 2004). Salinity intrusion is decreasing the net cropped area. Accumulation of salt in the soil root zone affect plant growth in the coastal region (Yadav et al., 2009). Salinity intrusion causes shortage of drinking water and declinitation of industrial production.

Saline water has bad impact upon human and livestock health. The impact includes pre-eclampsia and gestational hypertension in pregnant women, kidney diseases and rheumatism in human and milk productivity and reproductive health in cattle (Khan et al., 2011; SRTT, 2011). Salinity intrusion affects growth of forest species. It affects industrial growth. Pakshi paper mill was closed in 1993 due to salinity intrusion (Mirza, 1998).

The level of salinity, DO, BOD, Coliform bacteria in Bangladesh river water warrants checking the status of the water quality in the world's largest mangrove forest the Sundarbans located on the coast of Bangladesh (Gandeseca et al., 2011).

\subsection{HAOR Ecosystem}

Still the haor ecosystem in Bangladesh is in tact. Before the beginning of Indian water piracy, the Ganges basin too had its virgin ecosystem. With the construction of the Barak Dam, Indian water agression starts on the third largest river of Bangladesh.

In Sylhet, rainfall averages to about $4,000 \mathrm{~mm}$. June through October have more than $80 \%$ of the rain falls. Normally, annual temperature ranges $26-31^{\circ} \mathrm{C}$ in the premonsoon period (Mar to May), $28-31^{\circ} \mathrm{C}$ in the rainy season and $26-27^{\circ} \mathrm{C}$ in winter. Extreme temperatures over a ten-year interval during 1975-1984 were 6.4 and $39.3^{\circ} \mathrm{C}$

(http://bicn.com/wei/resources/nerp/wrs/ch3.htm). The stability of the Sylhet region climate is based on its water availability.

The huge mass of water in the Barak reservoir will be thermally statified. The top warm epilimnion layer will have constant temperature maintained by the action of wind and waves. The temperature drops quickly in the layer below it called metalimnion. The bottom layer called the hypolimnion will have cold water and will be oxygen deficient. The controlled weaker river discharge past the dam cannot regain the same oxygen level as the water in the river had before the construction of the dam. This oxygen deficiet reservoir water is not good for the fishes in the haor ecosystem. Reservoir water is open to be vulnerable from acid rains. The water from this acid deposition reservoir will not be good for the fish population.

The reservoir is located in a very earthquake-prone area. There occurred 22 earthquakes between 1926 and 2005 mostly of magnitude 6.0 of greater the last one being of magnitude 5.7 (http://www.earthquake.usgs.gov/regional/world/events/ 195008 15.php) The huge water mass will have its own characteristic frequency of oscillations. If an earthquake frequency nears or equals its characteristics frequency of oscillations, the resulting resonance frequency can demolish the dam. A wind event demolished the Tacoma Narrows Bridge in the USA on November 7, 1940 because of the resonance effect. On May 12, 2008, the 156-m high Chinese Zipingpu Dam came within $5.6 \mathrm{~km}$ of the epicenter of an 8.0 magnitude earthquake. The dam collapsed. As a result 70,000 people died, 375,000 were wounded, 39,000 were missing and 5,000,000 were made refugees. Its capacity was 1,120 million cubic meters. It would produce $760 \mathrm{MWt}$ electricity (http://www.internationalrivers.org/node/2806/. Chinese experts now hold the idea that the very dam triggered the earthquake. The Indian Tpaimukh will store 14 times more water. It has been about 160 years since any major earthquake hit this region. As days pass by, the occurrence of a devastating earthquake increases.

The reservoir will accumulate silt, nutrients and organic matter. Over the time when the reservoir eutrophies from nunicipal waste water, industrial wastes and runoffs from agricultural lands, algal growth starts. Algal decomposition will create oxygen deficiency in reservoir water. The hypolimnion layer remains devoid of oxygen. Hydrogen sulfide, methane and carbon dioxide produced from decomposition of organic matter that sink at the reservoir bottom, will remain dissolved in water under the high water pressure. A dangerous gas bubble may suddenly erupt at the surface of the reservoir triggered by an earthquake. Cameroon in Africa faced two such events-one in Lake Monoun in 1984 and the other in Lake Nyos in 1986, the latter shot carbon dioxide gas to $150 \mathrm{~m}$ in the air. In both cases, a cloud of heavier-than-air carbon dioxide rolled down the valleys depriving people and animals of oxygen. The first event killed 37 people and the second event 1700 people (Monastersky, 1994; Masters and Ela, 2007).

If the water is de-silted in the reservoir, water downriver will pick up sediment from the riverbed by the cutting action of water. This will result in the erosion of the bed and the banks of the river. Riverbeds can be deepened by several meters within a decade. The erosion in the Kushiyara which carries $80 \%$ of the Barak flow will be aggravated changing the map of Bangladesh. If the water is lightly de-silted, the reduced flow will close the origin of the Surma River which has already got a huge shoal at its origin. The shoal at the Surma's origin is because of its upward turn where the flow velocity reduces drastically. This shoal will favor rapid siltation because of sluggish stream movement over it.

In the event of the deteriorated quality of water released from the Barak Reservoir, ecological monitoring will be required of the water reaching the haors. 
Haor farmers cannot give agricultural supprt for Indian water release adaptations. This is beyond their supports for climate change adaptation.

Evey winter the arrival of migratory birds in the haors are a reflection for the sound health of the ecosystem. Wild living beings can best sense the nature. They could be sensetive at the controlled release of the reservoir water by the Indian.

\subsection{River Networking}

The networking will render the northern districts of Bangladesh deprived of the perennial river flows. India will interlink all the right bank and left bank tributaries of the Ganges. The right bank tributaries are the Upper Ganga with annual flow about 29 billion cubic meter (BCM), the Jamuna with annual discharge about 75 $\mathrm{BCM}$, the Tons having an annual discharge of $5 \mathrm{BCM}$, the Karamnasa having $7 \mathrm{BCM}$ annual discharge, the Son having an annual discharge of $23 \mathrm{BCM}$, the Punpun of annual discharge of $4 \mathrm{BCM}$ and the Burhi Gandak of annual discharge of $8 \mathrm{BCM}$. The left bank tributaries are the Ramganga with $15 \mathrm{BCM}$ flow, the Gomti with 8 BCM discharge, the Ghagra having $92 \mathrm{BCM}$ flow, the Gandak having 51 BCM flow and the Kosi having 61 BCM flow. The annual average water availability in the Ganges is about $525 \mathrm{BCM}$ and the usable water is about
300 BCM. The volume of water conserved is about 37 $\mathrm{BCM}$ as of 1995 . India is already pirating water from the Teesta and the Mahananda. Her next plan is to pirate water from the Brahmaputra's tributaries-the Manosh, the Sankosh and the Torsa (Fig. 16). The flow of the Ganges will decrease drastically and the river will become dry at Farakka and downstream through Bangladesh unless water is diverted from the Brahmaputra. The lean season flow of the Meghna will decrease substantially and the salinity front will advance to the north. The above discussions in the context of the Musa Khan and other ecosystems apply here, too.

\subsection{Signatory India's Disregard to the Ramsar Mission}

All that is appropriate to say is if all other signatories of the Ramsar Convention disregard their commitment of saving the wetlands, the world is going to change radically. This hypocrite nature of Indian politics puts her neighbor at very unease condition. Indian govertnment, after capturing all the water resources, is observing the World Water Day. It hears like making a farce of the international day. Indian government may better observe the Indian Water Conquest Day which will be the most appropriate per her actions.

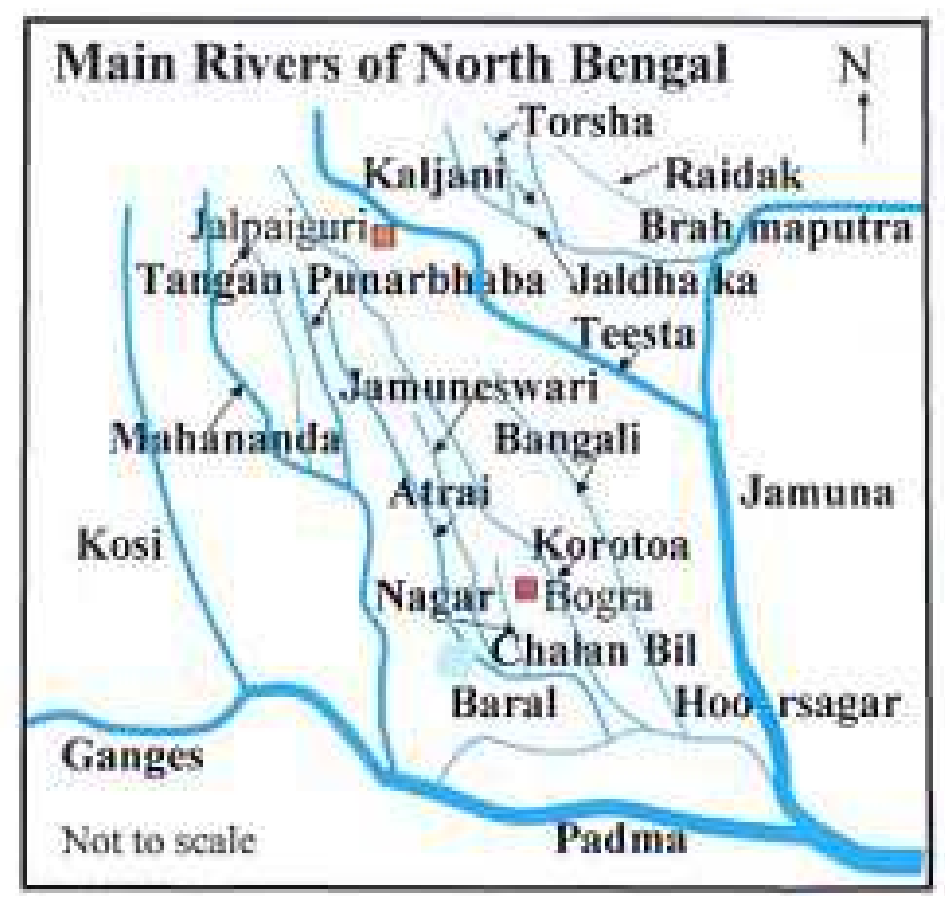

Fig. 16. Main Rivers of north Bengal (http://en.wikipedia.org/wiki/Torsa_River) 


\section{CONCLUSION}

Bangladesh's virgin ecosystem in the northwest has been totally changed from riverine wetland to that of a dry land at the cost of the loss of water resources, biodiversity, livelihood, fish production, cheap sources of nutrition, crop production, navigable routes and many others. It is no longer a healthy, sustainable and reproducible ecosystem. Scarcity of surface water resources, freshwater, potable water, recharging water has led to the world's worst man-made disaster-arsenic contamination of groundwater. It is undermining infrastructure of the society-breaking families and creating rehabilitation problem. Water scarcity has caused livelihood problem and has displaced people. Potable water stress represents one of the greatest concerns of the human wellbeing. Water scarcity presents a very serious challenge to the food security, prosperity of individuals, communities, regions, as well as to the nation. It should be a matter of grave concern as to how the next generation will survive when the current generation is massively exploiting the groundwater and it takes generations to replenish it.

As to the micro-level climate change, Bangladesh's northwestern part has observed summertime high and wintertime low temperatures and erratic rainfall.

India's water aggression even goes to the extent of changing the map of the Bangladesh ecosystem.

On the coast, Bangladesh is losing land. Salinity front is advancing inland. Bangladesh's dwindling rivers carry progressively deteriorated quality of water.

The effect of the Tipaimukh Dam will destroy the haor ecology. The grand river networking plan of the neighbor is going to bring radical changes in the ecosystem as inferred from the local case studies. India should be reminded of these potential effects along with her Ramsar agreement not to trigger desertifing the Bangladesh delta.

Since the national security dimensions include economic growth and development, both visible and predicted challenges to Bangladesh's ecosystem have made her national security shaky. They risk people's welfare, political stability, economic stability and can lead to civil unrest.

With both the northwest and northeast parts of Bangladesh undergoing ecocide, the country cannot be safe from the challenges of climate change whose devastating threats of hitting with extreme events like powerful cyclones (November 15, 2007) still haunt the people. Frequency and intensity of extreme events renders people's welfare and livelihoods less secure.

For survivability, Bangladesh must have to bring to reality that water is the asset and water is the future.

\subsection{Recommendations}

Government of Bangladesh has to prioritize the issue of the water problem. Water is her asset. Water is her future. She should be determined for the people's wellbeing and the country's development. Since she has failed, over a period of forty years, to save her interests on a bilateral basis with India, she should take immediate and effective steps for fair share of the international river water India has been pirating of under the UN supervision. Any further delay is going to give leeway to her land grabbers.

Rivers is the mother of Bangladesh. So long rivers have given services. It is urgency for Bangladesh to give back. She should have a master plan of dredging rivers and their canals for water storage and for inland distribution to the depleted surface water bodies to reestablish the wetland ecosystem. This will help, to some extent, in the gradual mitigation of all the problems including groundwater arsenic contamination, fish scarcity, erratic climate. She can charge the upstream country for the dredging cost of the rivers since upstream country's water piracy has regionally silted her rivers and has depleted her water resources.

Bangladesh may further think over inland river networking in case water is not accessible to all the rivers. As per need, integrated river basin management may be her one of the options.

Since the saving of the biodiversity is an international slogan of the time, Bangladesh should ask the UN to enforce strict international laws to stop any more means of upstream water piracy to save the downstream biodiversity. Sanctions should be put in place for the violators of the law.

Bangladesh may keep an option of approaching the international court with this grave issue of ecocide she has been facing over decades.

Since the groundwater is extracted so massively for all water-related jobs in the absence of little or no recharge, improvement of water use efficiency needs to be introduced (Boutraa, 2010).

Bangladesh media should not be scared to publish the factual scenarios.

India should honor riparain human rights and follow environmental ethics in the management of international river water and keep her commitment to the Ramsar Convention.

\section{ACKNOWLEDGEMENT}

I am thankful to the persons and/or agencies whose illustrations and facts I have used in this article.

\section{REFERENCES}

Adel, M.M., 2001. Effect on water resources from upstream water diversion in the Ganges basin. J. Environ. Q., 30: 356-368. PMID: 11285895 
Adel, M.M., 2002. Man-made climatic changes in the Ganges basin. Int. J. Climatol., 22: 993-1016. DOI: 10.s1002/joc. 732

Adel, M.M., 2005. The background state leading to arsenic contamination of Bengal basin groundwater. J. Water Health, 3: 435-452. PMID: 16459848

Adel, M.M., 2012a. Jaladasyupana (in Bengali). Thikana, 23: 163-169.

Adel, M.M., 2012b. Mamatadeer Mathabatha Hooghly Gangar Sanghare na Farakkar Fatole (in Bengali). Thikana, 23: 10-94.

Ahmed, K. and N. Hassan, 1986. Nutrition Survey of rural Bangladesh, 1981-82. 1st Edn., University of Dhaka, Dhaka, pp: 231.

Aung, T., A. Singh and U. Pasad. 2009. Sea level threat in Tuvalu. Am. J. Appplied Sci., 6:169-1174. DOI: 10-3844/ajassp.2009.1169.1174

Boutraa, T., 2010. Improved water use efficviency in irrigated agriculture: A review. J. Agron., 9: 1-8. DOI: $10.3923 /$ ja.2010.1.8

Dugan, P.J., 1990. Wetland Conservation: A Review of Current Issues and Required Action. 1st Edn., IUCN, Gland, Switzerland, ISBN-10: 2831700159, pp: 96.

Durmishi, B. H., M. Ismaili, A. Shabani and Sh. Abduli. 2012. Drinking water quality assessment in Tetora Region, Am. J. Environ. Sci., 8:162-169. DOI: 10.388/ajessp.2012.162.169

FAO, 1988. Agro-Ecological Regions Of Bangladesh. 1st Edn., FAO, Rome.

Freeze, R.A., 1969. The mechanism of natural groundwater recharge and discharge: 1. One-dimensional, vertical, unsteady, unsaturated flow above a recharging or discharging ground-water flow system. Water Resources Res., 5: 153-171. DOI: 10.1029/WR005i001p00153

Gandeseca, S., N. Rosli, J. Ngayop and C.I. Arianto, 2011. State of water quality based on the physico-chemical assessment on river water at wildlife sanctuary Sibuti Mangrove Forest Miri Sarawak. Am. J. Environ. Sci., 7: 269-275. DOI: 10.3844/ajessp.2011.269.275

Islam, M.R., 2004. Where Land Meets the Sea: A Profile of the Coastal Zone of Bangladesh. 1st Edn., Program Development Office for Integrated Coastal Zone Management Plan, Dhaka, Bangladesh, ISBN10: $9840517198, \mathrm{pp}: 317$.

IWRB, 1992. Action Program for the Conservation of Wetlands in South and West Asia. Northeast Regional Water Resources Development Project (FAP 6), Government of Bangladesh, Dhalka.

Jhunjhunwalla, B., 2009. Economics of Hydropower. 1st Edn., Gyan Publishing House, Delhi, ISBN-10: 9788178357409, pp: 306.
Khan, A.A., 1993. Freshwater wetlands in Bangladesh: Opportunities and options, in Freshwater Wetlands. In: Freshwater Wetlands in Bangladesh : Issues and Approaches for Management, Nishat, A., Z. Hussain, M.K. Roy and A. Karim, (Eds.)., IUCN-The World Conservation Union, Dhaka, Bangladesh, pp: 283-283.

Khan, A.E., A. Ireson, K. Kovats, S.K. Mojumder and A. Khusru et al., 2011. Drinking Water salinity and maternal health in coastal bangladesh: Implications of climate change. Environ. Health Perspective, 119: 1328-1332. DOI: 10.1289/ehp.1002804

Khan, M.S., E. Haq, S. Huq, A.A. Rahman and S.M.A. Rashid et al., 1994. Wetlands of Bangladesh. 1st Edn., Bangladesh Centre for Advanced Studies in associated with Nature Conservation Movement, Dhanmondi, Dhaka, ISBN-10: 9848121013, pp: 91.

Krantz, D.H., 1999. The null hypothesis testing controversy in psychology. J. Am. Stat. Assoc., 94: 1372-1381.

Masters, G.M. and W.P. Ela, 2007. Introduction to Environmental Engineering and Science. 3rd Edn., Prentice Hall, Upper Saddle River, New Jersey, ISBN-10: 0131481932, pp: 720.

Mirza, M.M.Q., 1998. Diversion of the Ganges Water at Farakka and Its Effects on Salinity in Bangladesh. Environ. Manage., 22: 711-722. DOI: 10.1007/s002679900141

Monastersky, R., 1994. Cameroon's killer lakes: A rising threat. Sci. News, 145: 215-215.

NFB, 2000. Flood news. News From Bangladesh.

O'Connor, D.J. and W.E. Dobbins, 1958. Mechanism of reactions in natural streams. Trans. Am. Soc. Civil Eng., 153: 641641.

Prakash, A., 1998. Farakka barrage: Cause for concern.

Rana, M.P., M.S.I. Sohel, S. Akhter and M.S. Alam, 2010. Haor based livelihood dependency of a rural community: A study on hakaluki haor in Bangladesh. Proc. Pak. Acad. Sci., 47: 1-10.

Sattar, A., 1996. Farakka Bangladesher Bhagyo Zekhane Bondi (in Bengali). Padma-Jamuna Prakashani, Dhaka, Bangladesh.

SPARSO, 1993. Space research organization.

SRTT, 2011. Salinity prevention and mitigation initiative. Agriculture and Water Resource Development.

Tchobanoglous, G. and E.D. Schroeder, 1985. Water Quality: Characteristics, Modeling, Modification. 1st Edn., Addisionm-Wesley, Reading, MA., ISBN10: 0201054337, pp: 768.

Thomann, R.V. and J.A. Mueller, 1987. Principles of Surface Water Quality Modeling and Control. 1st Edn., Harper and Row, New York, ISBN-10: 0060466774, pp: 644.

Wasson, R.J., 2003. A sediment budget for the GangaBrahmaputra catchment. Curr. Sci., 84: 1041-1047.

Yadav, J.S.P., H.S. Sen and B.K. Bandyopadhyay, 2009. Coastal soils-management for higher agricultural productivity and livelihood security with special reference to India. J. Salinity Water Q., 1: 1-13. 